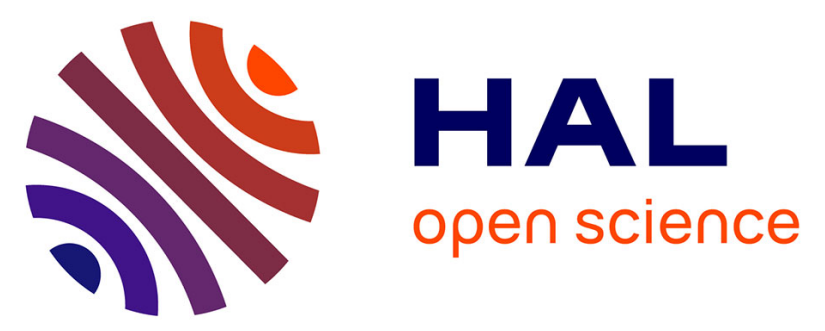

\title{
Bioorthogonal Conjugation of Transition Organometallic Complexes to Peptides and Proteins: Strategies and Applications
}

\author{
Michèle Salmain, Nathalie Fischer-Durand, Bogna Rudolf
}

\section{To cite this version:}

Michèle Salmain, Nathalie Fischer-Durand, Bogna Rudolf. Bioorthogonal Conjugation of Transition Organometallic Complexes to Peptides and Proteins: Strategies and Applications. European Journal of Inorganic Chemistry, In press, 2020 (1), pp.21-35. 10.1002/ejic.201900810 · hal-02332497

\section{HAL Id: hal-02332497 \\ https://hal.sorbonne-universite.fr/hal-02332497}

Submitted on 24 Oct 2019

HAL is a multi-disciplinary open access archive for the deposit and dissemination of scientific research documents, whether they are published or not. The documents may come from teaching and research institutions in France or abroad, or from public or private research centers.
L'archive ouverte pluridisciplinaire HAL, est destinée au dépôt et à la diffusion de documents scientifiques de niveau recherche, publiés ou non, émanant des établissements d'enseignement et de recherche français ou étrangers, des laboratoires publics ou privés. 


\title{
Bioorthogonal conjugation of transition organometallic complexes to peptides and proteins: Strategies and applications.
}

\author{
Michèle Salmain, ${ }^{*[a]}$ Nathalie Fischer-Durand,[a] Bogna Rudolf[b]
}

[a] Dr. Michèle Salmain, Dr. Nathalie Fischer-Durand

Sorbonne Université, CNRS

Institut Parisien de Chimie Moléculaire

4 place Jussieu 75005 Paris, France

michele.salmain@sorbonne-universite.fr

http://ipcm.fr/article697.html

[b] Prof. Dr. Bogna Rudolf

Department of Organic Chemistry

Faculty of Chemistry

University of Lodz

91-403 Lodz, Poland

\begin{abstract}
The advent of bioorthogonal chemistry has revolutionized the common practices in protein bioconjugation and contributed to a large extent to the development of chemical biology, a discipline aimed at studying biological / biochemical processes / events in their natural setting (living cells, whole organisms) using dedicated chemical tools. This minireview intends to provide an up-to-date overview on the various bioorthogonal strategies implemented for the conjugation of transition organometallic entities to peptides, peptide nucleic acids and proteins with a focus on targeted applications, i.e. fluorescence- or radio-labeling for imaging, controlled delivery of therapeutic agents and bioanalysis.
\end{abstract}

\section{Keywords}

Click chemistry; peptide nucleic acid; cycloaddition; ferrocene; manganese

\section{Introduction}

Within the last two decades or so, protein bioconjugation methods have undergone a dramatic evolution as the concept of bioorthogonal ligation was introduced.[1] Until then, protein bioconjugation had been mostly limited to the modification of amine and thiol nucleophilic functions of lysine and cysteine residues with electrophiles so that they had to be performed on pure protein samples. Moreover, reactions involving lysines are by essence not regioselective owing to the high number of these residues in most proteins giving rise to a complex mixture of bioconjugates. In contrast, bioorthogonal ligation methods allow reactions to take place with high chemoselectivity in complex biological settings, including living cells and higher organisms. ${ }^{[2]}$

To be recognized as bioorthogonal, a chemical transformation must fulfill several criteria. Reagents must tolerate the aqueous environment and nucleophiles abundantly present in cells. They should be kinetically, thermodynamically and metabolically stable and naturally non toxic to living systems. Moreover, when dealing with biomolecule 
modification in biological settings such as cells, the issue of reaction rate becomes pivotal since species to be conjugated are usually present in low amount.[3] Consequently, the kinetics of the bioorthogonal reaction should be adjusted to reduce the concentration of the reaction partner to the minimum while product formation occurs in a reasonable timescale. ${ }^{[4]}$

Applications of bioorthogonal chemistry in chemical biology are growing steadily. ${ }^{[5]}$ The most popular one is certainly the (metabolic) labeling of biopolymers with luminescent probes for tracking purposes. ${ }^{[6]}$ Bioorthogonal reactions (especially $\mathrm{CuAAC},{ }^{1}$ see below) have also proven invaluable for enzyme activity profiling, ${ }^{[7]}$ drug targets identification ${ }^{[8]}$ and other biomedical applications.

On the other hand, synthetic transition organometallic complexes have distinct and sometimes unique properties whose input in life sciences has been recognized from the 1980s specially for the development of new (radio)pharmaceuticals for imaging and therapy as well as optical and electrochemical markers. ${ }^{[9]}$ Table 1 gathers the range of bioorthogonal reactions that have been used for the bioconjugation of transition organometallic complexes to date. Except for CuAAC and Sonogashira cross-coupling that require metal catalysis to take place, the other ligation methods occur spontaneously and at variable reaction rates.

This minireview is intended to give a comprehensive overview of the works reported so far on the bioorthogonal ligation of transition organometallic entities to peptides, peptide-like polymers, proteins and occasionally to an oligonucleotide. Let us note however that those involving proteins are still rather scarce. For reasons of space, articles dealing with coordination / inorganic complexes were intentionally omitted. General methods for labeling of peptides and proteins with luminescent rhenium(I) and iridium(III) complexes have been reviewed recently by Lo and coworkers[10] and Connell and Donnelly[11]. Radio-labeling of biopolymers by click chemistry has also been reviewed.[12] Synthetic methods to prepare organometallic peptide bioconjugates and their application as antibacterial agents have been comprehensively reviewed in 2016 and 2017, respectively.[13] All the other bioconjugation methods involving native protein functional groups are also intentionally omitted. Such an information may be found to the most recent review on artificial metalloenzymes.[14]

\footnotetext{
${ }^{1}$ Abbreviations : ADIBO, azadibenzocyclooctyne; aTf, apo-transferrin; BBS, bombesin; BCN, bicyclononyne; bpea, bis(pyrazolyl)ethylamine; BPS, bathophenanthroline disulfonic acid; BSA, bovine serum albumin; cMBP, c-Met binding peptide; CORM, carbon monoxide releasing molecule; CMIA, carbonyl metalloimmunoassay; CuAAC, copper-catalysed azide-alkyne cycloaddition; DBCO, dibenzocyclooctyne; DIPEA, diisopropylethylamine; dpa, dipicolylamine; EDC, ethyl diisopropyl

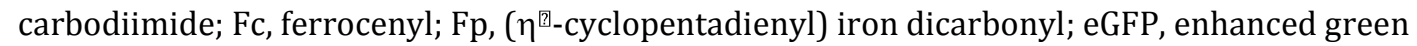
fluorescence protein; GRPR, gastrin-releasing peptide receptor; HSA, human serum albumin; HTf, holotransferrin; iEDDA, inverse electron-demand Diels-Alder; IgG, immunoglobulin G; Mb, myoglobin; MDM2, mouse double minute 2; MSH, melanocyte stimulating hormone; NHS, N-hydroxysuccinimide; NLS, nuclear localization signal; PNA, peptide nucleic acid; PLIM, photoluminescence lifetime imaging microscopy; ppy, 2-phenylpyridine; pqe, 2-phenylquinoline; ROS, reactive oxygen species; SPAAC, strained-promoted azide-alkyne cycloaddition; SPANC, strained-promoted alkyne-nitrone cycloaddition; SPECT, single photon emission computed tomography; SPPS, solid-phase peptide synthesis; Tat, transactivator of transcription; TBAF, tetrabutylammonium fluoride; TBTA, tris(benzyltriazolylmethyl)amine; TGF, transforming growth factor; THPTA, tris(hydroxypropyltriazolylmethyl)amine; TMS, trimethylsilyl; tpm, tris(pyrazolyl)methane.
} 
Table 1. Bioorthogonal reactions used to conjugate transition organometallic complexes

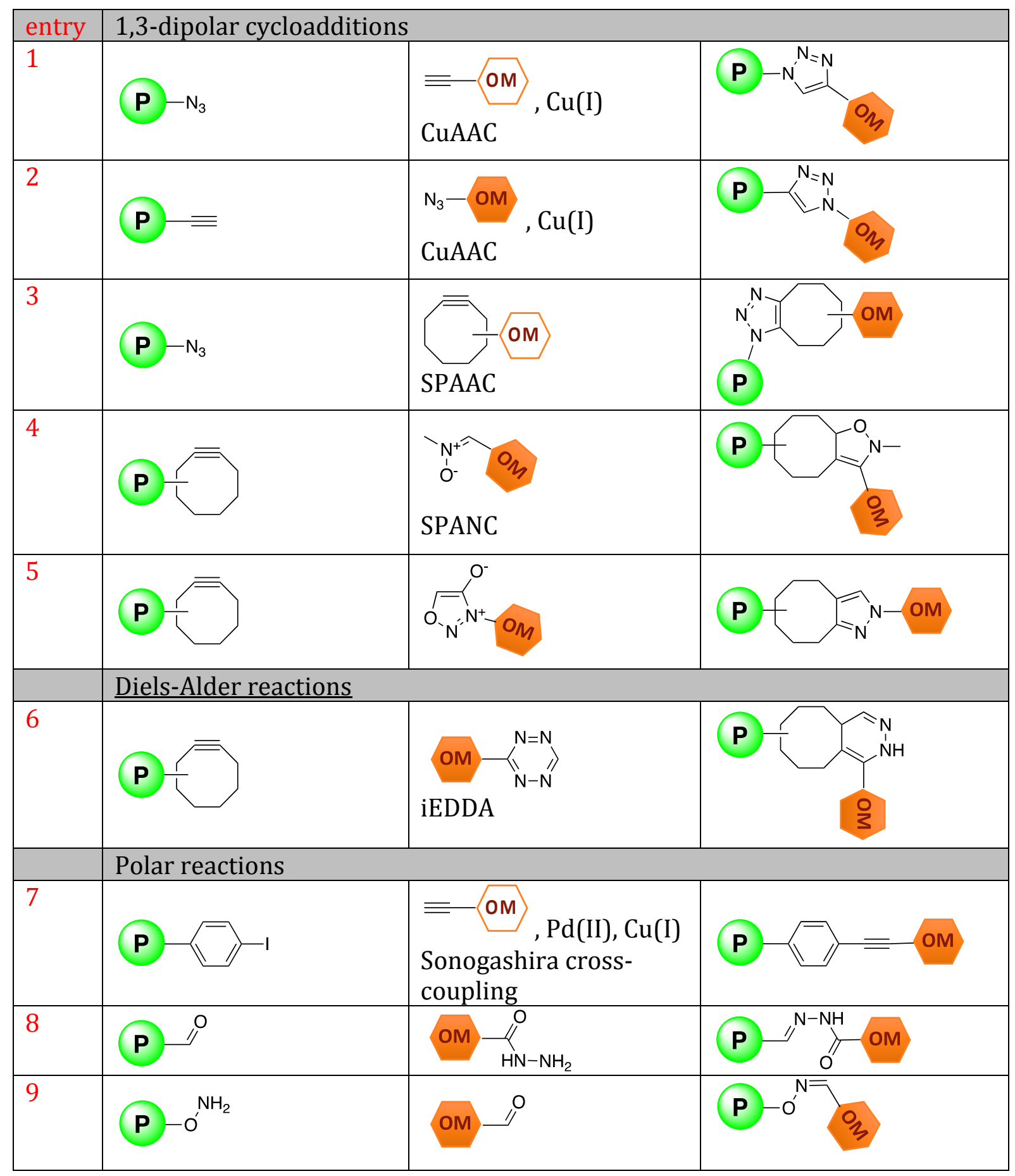




\section{1,3-dipolar cycloadditions}

\subsection{Copper-catalysed azide - alkyne cycloadditions (CuAAC)}

The 1,3-dipolar [3+2] cycloaddition between azides and terminal alkynes (AAC) also known as the "click reaction" (Table 1, entries 1 and 2) is one of the most powerful ligation methods discovered to date, owing to the small size of the two partner functions involved in the reaction, their relative inertness and their absence in biological molecules and media. Although this reaction has been introduced in the early $60 \mathrm{~s}$ by Huisgen, ${ }^{[15]}$ the real breakthrough in chemical biology was provided independently by Sharpless and Meldal's groups in 2002,[16] when they both found that $\mathrm{Cu}(\mathrm{I})$ was an outstanding catalyst of this reaction. Not only reaction rates are tremendously accelerated but the reaction becomes regioselective as only the 1,4-substituted 1,2,3triazole isomer is obtained. Moreover, the compatibility of copper-catalyzed azidealkyne cycloaddition (CuAAC) with other functional groups qualifies it as a truly bioorthogonal reaction that is now extensively exploited in various fields including peptide / protein conjugation.[17]

\subsubsection{Chelate then click strategy}

Several transition organometallic complexes carrying an azido or a terminal alkynyl substituent (Figure 1) have been synthesized and conjugated to biopolymers carrying the partner handle by CuAAC. Not surprisingly ferrocene was the first one to be conjugated this way to the biologically active peptide[Leu $\left.{ }^{5}\right]$-enkephalin,[18] a neuropeptide that binds to opioid receptors and involved in analgesia as well as stress processes.[19] This pentapeptide was prepared by solid-phase peptide synthesis (SPPS) and 4-pentynoic acid was coupled to the $\alpha$-amino group at the $\mathrm{N}$-terminus of the peptide sequence. After cleavage from the solid support, ferrocenylazide $\mathbf{1}$ was successfully clicked to the functionalized peptide under classical conditions $\left(\mathrm{CuSO}_{4}+\right.$ ascorbate in ${ }^{t} \mathrm{BuOH} / \mathrm{H}_{2} \mathrm{O}$ 1:1). Alternatively, $\mathrm{CuAAC}$ was also achieved with the peptide still on the solid phase in the presence of CuI and excess DIPEA in DMF.

Following this initial report, other teams became interested in coupling transition organometallic moieties to peptides via CuAAC for various purposes. In 2009, Schatzschneider and co-workers designed a photoCORM peptide conjugate for selective delivery of $\mathrm{CO}$ to cancer cells. ${ }^{[20]}$ The acronym CORM was initially coined by Motterlini and co-workers in their pioneering work, ${ }^{[21]}$ and refers to transition metal carbonyl complexes that are able to release carbon monoxide, spontaneously or under specific stimulation, ${ }^{[22]}$ for biomedical applications.[23] To this aim, the $\alpha$-amino group at the $\mathrm{N}$ terminus of Thr-Phe-Ser-Asp-Leu, a peptide sequence representative of the transactivation domain of the tumor suppressor protein p53 within the regulatory protein MDM2, was acylated with azidoacetic acid. After cleavage / deprotection, the $\mathrm{Mn}(\mathrm{CO})_{3}$ complex of tris(pyrazolyl)methane (tpm) ligand 2 was clicked to the functionalized peptide under typical Sharpless conditions to afford the modified peptide in good yield. Upon UV irradiation, 1.7 equivalents of $\mathrm{CO}$ were released per conjugate. In the same vein, the same team reported the conjugation of the bis(pyrazolyl)imine $\mathrm{Mn}(\mathrm{CO})_{3}$ complex 3 to a pentapeptide representative of TGF- $\beta$, a cytokine involved in cell proliferation, differentiation, motility, adhesion and apoptosis.[24] Slow decomposition of the conjugated peptide was observed probably due to hydrolysis of the imine bond within the tripodal ligand. 
Azido methyl ruthenocene 4 was also reported as CuAAC orthogonal partner for the labeling of [Leu $\left.{ }^{5}\right]$-enkephalin, either at the $\mathrm{N}$-terminus modified by 4-pentynoic acid or at the side chain of the non natural aminoacid propargylglycine.[25]
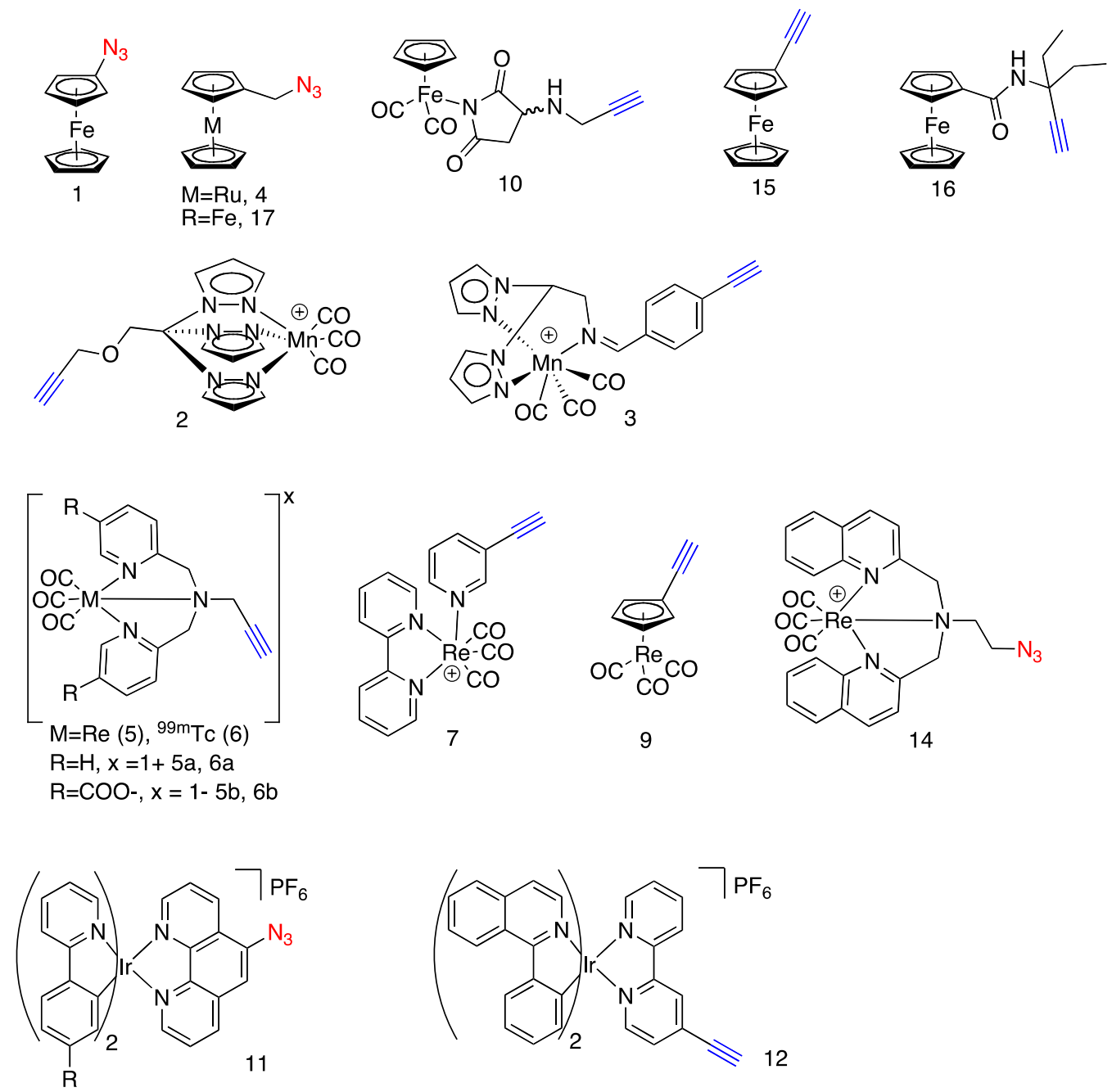

$\mathrm{R}=\mathrm{H}, \mathrm{COOH}, \mathrm{CONH}\left(\mathrm{CH}_{2} \mathrm{CH}_{2} \mathrm{O}\right)_{4} \mathrm{H}$

Figure 1. Transition organometallic complexes designed for CuAAC

Rhenium and technetium tricarbonyl complexes of tridentate dipicolylamine (dpa) ligands were conjugated to a peptide analogue of the $\alpha$-melanocyte stimulating hormone $(\alpha-\mathrm{MSH})$ by $\mathrm{CuAAC}$ for selective imaging of melanoma cells. ${ }^{[26]}$ In the first step, an azido group was appended to the peptide by S-alkylation of the non essential cysteine residue with 2-bromo-N-(3-azidopropyl)-acetamide. In a second step, click reaction with the $\mathrm{Re}$ and $99 \mathrm{mTc}$ complexes $\mathbf{5 a}, \mathbf{5 b}, \mathbf{6 a}, \mathbf{6} \mathbf{b}$ yielded the expected peptide conjugates in very good yield. High cellular uptake of the $99 \mathrm{mTc}$ conjugate including the carboxylatesubstituted dpa ligand was found in melanoma cells. Coincubation with excess unlabeled peptide significantly reduced cell uptake of peptide conjugates, indicating that it was mediated by the membrane receptor MC1R. Biodistribution studies in vivo showed moderate accumulation of the radiotracer derived from the hydrophilic complex $\mathbf{6 b}$ in melanoma xenografts but failed to decrease the hepatobiliary retention.

In 2014, Gasser and co-workers reported the labeling of the lipopeptide myr-Lys-Tat with the luminescent rhenium tricarbonyl complex 7.[27] Tat peptide is part of the 
transactivator of transcription of HIV-1 and was the first cell penetrating peptide to be identified.[28] $\omega$-Azidolysine was inserted within the lipopeptide sequence in between the myristyl chain and the Tat peptide sequence by SPPS. The click reaction took place under the conditions reported by Fokin $\left(\mathrm{CuSO}_{4}+\right.$ ascorbate + TBTA). Fluorescence microscopy of HeLa incubated with the conjugate showed higher cellular uptake compared to the rhenium complex alone.

The iClick reaction was used once for conjugation of gold(I) complexes to a biologically active peptide. ${ }^{29]}$ In short, iClick is the version of azido-alkyne cycloaddition for which the azide and / or the alkyne is coordinated to a transition metal.[30] Interestingly, no catalyst is required for the cycloaddition to take place since the azide / alkyne is sufficiently activated through its metal coordination. In the work by Metzler-Nolte and co-workers, the mitochondria-targeting sequence L-4-I-Phe-D-Arg- Phe-Lys was synthesized by SPPS. With the peptide still on the solid support, a terminal alkyne moiety was introduced by Sonogashira reaction with ethynyl-TMS followed by deprotection with TBAF. Cycloaddition with the Au(I)(phosphine) azido complexes 8 proceeded in DMF in the absence of copper catalyst (Scheme 1) to afford, after cleavage / deprotection, gold-peptide conjugates where gold is coordinated to the formed 1,2,3triazole ligand via a gold-carbon bond. ${ }^{[31]}$ The cytotoxic activity of the gold-peptide conjugates on the breast cancer cell line MCF-7 was found to be lower than that the $\mathrm{Au}(\mathrm{I})$ precursors, most likely because of poor cellular uptake. Nevertheless, one of the gold-peptide conjugates was shown to induce overproduction of ROS, decrease of the mitochondrial membrane potential and eventually trigger apoptosis.

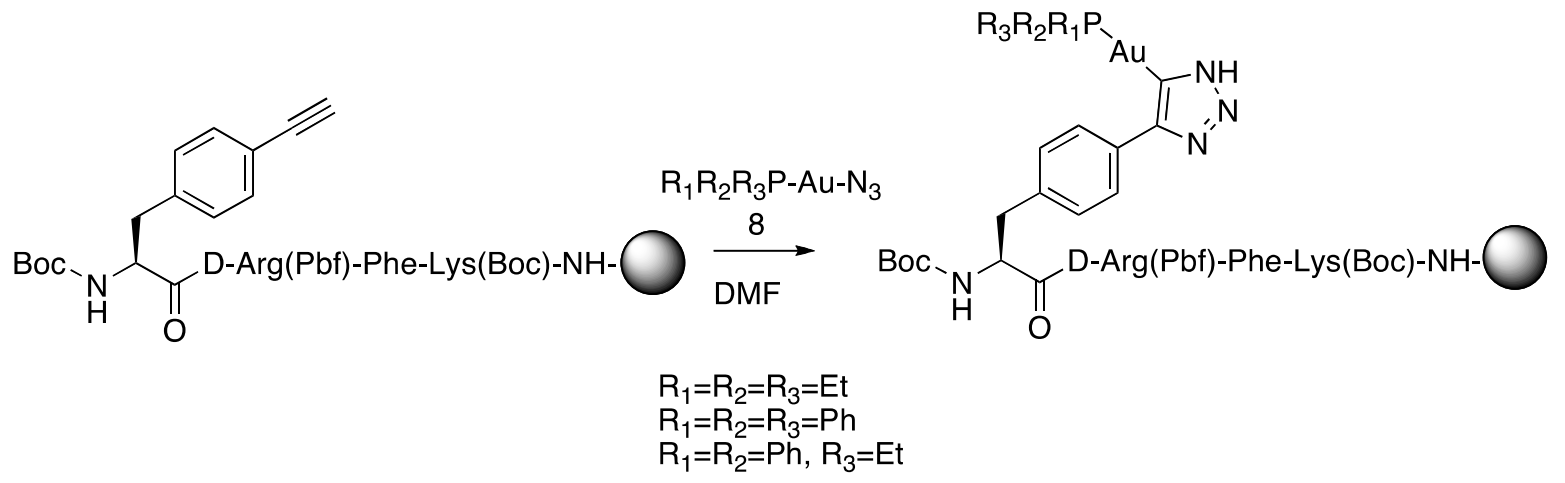

Scheme 1. Labeling of a peptide by iClick

Few examples of CuAAC between a transition organometallic complex and a protein have been reported to date. Two of them aimed at incorporating a metal carbonyl entity into a protein to take advantage of its strongly absorbing properties in the mid-IR spectral range owing to the presence of the CO ligands giving rise to bands in the 1800$2150 \mathrm{~cm}^{-1}$ region. In the first example, the cyrhetrenyl complex 9 carrying a terminal alkyne group was site-selectively conjugated to the C-terminal domain of the ribosomal protein L9 (CTL-9) including an azidohomoalanine residue at position 109.[32] Quantitative incorporation of the metal carbonyl entity was reached and had no effect on the protein structure. Furthermore, the presence of the rigid triazole linker prevented any non specific interaction with the protein surface. In the second example, we successfully labeled a model protein, namely bovine serum albumin (BSA), with cyclopentadienyl iron dicarbonyl (Fp) entities using a two-step process. ${ }^{[33]}$ Azido groups were first introduced on BSA by diazo transfer reaction with imidazole-1-sulfonyl azide with the amino groups carried by the lysine residues (scheme 2).[34] 

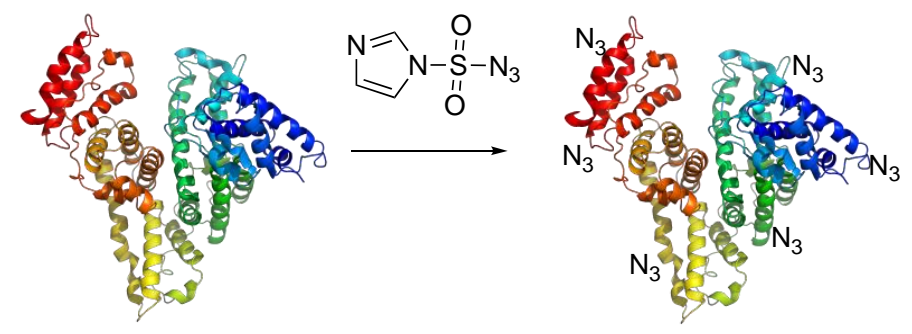

Scheme 2. Azidination of BSA

The second step consisted in CuAAC with the Fp derivative $\mathbf{1 0}$ in the presence of $\mathrm{CuSO}_{4}$, ascorbate and BPS. In average, $8 \mathrm{Fp}$ entities were found to be incorporated into BSA as assayed by IR spectroscopy. In a similar fashion, the luminogenic, cyclometalated iridium(III) complex carrying an azide handle $\mathbf{1 1}$ was conjugated to alkyne-tagged HSA in the presence of $\mathrm{CuSO}_{4}$, ascorbate and THPTA. ${ }^{[35]}$

The photoluminescent cyclometalated iridium(III) complex carrying a terminal alkyne group 12 was very elegantly used to image protein synthesis within living HeLa cells by photoluminescence lifetime imaging microscopy (PLIM). In brief, HeLa cells were metabolically labeled with azidohomoalanine and further treated with complex 12 in the presence of $\mathrm{Cu}_{2} \mathrm{O}$ nanoparticles as catalyst. Labeling of newly synthesized proteins by 12 was monitored in real time in living cells in a wash-free fashion thanks to the large difference of luminescence lifetime between the unreacted azido complex and the resulting triazole that allowed perfect discrimination between both forms of complex. ${ }^{[36]}$

CuAAC has also been employed for the ligation of transition organometallic entities to peptide nucleic acids (PNA). PNA are synthetic surrogates of nucleic acids (DNA and RNA) where the sugar-phosphodiester backbone is replaced by a pseudopeptidic backbone of repeating $\mathrm{N}$-(2-aminoethyl)glycine units.[37] Compared to their natural counterparts, PNA display higher affinity for the complementary DNA / PNA sequence, better mismatch sensitivity and are insensitive to nuclease / protease degradation. ${ }^{[38]}$ PNA are typically synthesized by SPPS using Fmoc-protected monomers. ${ }^{[39]}$ MetzlerNolte and co-workers introduced several routes to "click" an organometallic entity to PNA. The first pathway made use of the alkyne-containing PNA monomer 13 (figure 2), which was conveniently inserted either at the $\mathrm{C}$-terminus, the $\mathrm{N}$-terminus or in the middle of the PNA sequence during SPPS.

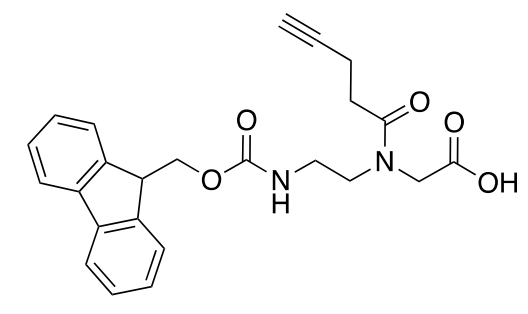

Figure 2. PNA monomer 13 for labeling by CuAAC

Conjugation of ferrocenylazide $\mathbf{1}$ was then achieved on the solid phase as described above.[40] The stability of the duplexes formed by hybridization between Fc-labeled PNA and complementary DNA sequence was found to depend on the position of ferrocenyl entity in the PNA sequence. While insertion at the C- or N-terminus of the sequence did 
not affect the melting temperature of the hybrids, positioning in the middle of the sequence markedly destabilized the duplexes. ${ }^{[41]}$ In the same vein, the PNA monomer 13 was inserted into a 22mer PNA at the N-terminus and the luminescent, azide-containing bis(quinoline) $\operatorname{Re}(\mathrm{CO})_{3}$ complex 14 was clicked to the PNA on the solid phase. Upon excitation at $347 \mathrm{~nm}$, the PNA-Re(CO) $)_{3}$ - DNA duplex showed emission features similar to the starting rhenium complex. The labeled PNA oligomer was successfully transfected by electroporation in HeLa cells as shown by fluorescence microscopy. Furthermore, a PNA-Re(CO) $)_{3}$ conjugate targeting eGFP behave as an antisense agent since it significantly decreased its expression in genetically modified HeLa cells.

The second pathway consisted in coupling a terminal alkyne or an azide by acylation of the $\alpha$-amino group at the $\mathrm{N}$-terminus of the PNA sequence followed by CuAAC with the organometallic complex carrying the partner function. For example, coupling of propynoic acid or azidoacetic acid followed by $\mathrm{CuAAC}$ with each of the four ferrocenyl derivatives 1, 15, 16 and 17 with PNA still on the solid support afforded the expected PNA conjugates for 1, 15 and $\mathbf{1 6}$ after deprotection/cleavage.[42] Mass analysis of the click product of $\mathbf{1 6}$ revealed that the ferrocenyl entity was missing, presumably because it did not sustain the harsh conditions required for cleavage and deprotection. This pitfall was easily remedied by carrying out CuAAC after cleavage. The four PNA-Fc conjugates displayed distinct redox profiles with $\mathrm{E}_{1 / 2}$ ranging from 256 to $536 \mathrm{mV}$ vs. $\mathrm{Ag} / \mathrm{AgCl}$ in MOPS buffer $\mathrm{pH} 7.4$ making them potential electrochemical probes for DNA analysis.

Ethynylferrocene $\mathbf{1 5}$ was also reported to react by $\mathrm{CuAAC}$ with an azido-proline residue carried by a macrocyclic peptide to yield the corresponding ferrocenyl triazole that showed activity as an inhibitor of HIV-1 cell infection by suppressing gp120 receptor binding.[43]

\subsubsection{Click-then-chelate strategy}

An alternative pathway is to conjugate a chelating ligand (Figure 3 ) to the peptide by $\mathrm{CuAAC}$ then perform the metalation reaction at the last step.

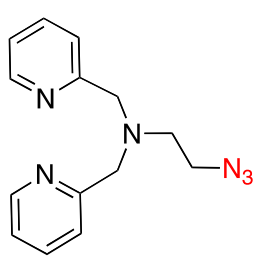

18

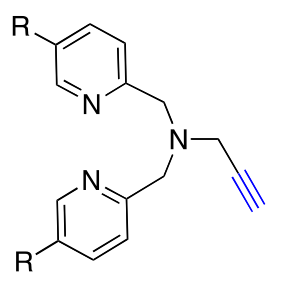

$\mathrm{R}=\mathrm{H}, 19$ $\mathrm{R}=\mathrm{CO}_{2} \mathrm{H}, 20$

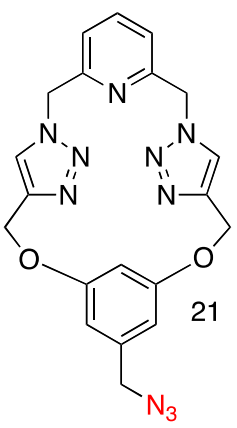

22

Figure 3. Clickable chelating ligands for the click-then-chelate strategy

This synthetic strategy is particularly well suited to prepare radiotracers for SPECT owing to the short half lives of gamma-emitting radioelements ( $6 \mathrm{~h}$ for ${ }^{99 \mathrm{~m} T c}$ ). For instance, the azide-bearing dpa derivative 18 was clicked to a PNA oligomer carrying a terminal alkyne group at the N-terminus. ${ }^{[44]}$ After cleavage from the solid support, metalation with $99 \mathrm{~m} \mathrm{Tc}$ was performed via the precursor species $\left[{ }^{99 \mathrm{~m} T c}(\mathrm{CO})_{3}\left(\mathrm{OH}_{2}\right)_{3}\right]^{+}$ using the IsoLink® kit "Carbonyl labeling Agent". Very high radiolabeling yield was 
obtained. Biodistribution studies in normal rats showed accumulation of the conjugate in the kidneys.

Alternatively the alkyne-bearing dpa ligands 19 and 20 were clicked under standard Sharpless conditions to the $\alpha$-MSH derived peptide previously used in the chelate then click approach (see above).[26] After purification of the conjugated peptides, metalation with $\left[\mathrm{Re}(\mathrm{CO})_{3}\left(\mathrm{OH}_{2}\right)_{3}\right](\mathrm{TfO})$ yielded species with the right molecular mass but different retention times. This was rationalized by the persistence of coordinated copper ion in the peptide conjugates after $\mathrm{CuAAC}$ that hindered proper coordination of rhenium to the dpa tripodal ligand. The tridentate macrocyclic ligand $\mathbf{2 1}$ was clicked to a cyclic pentapeptide comprising the RGD sequence and propargylglycine. Metalation with $\left[\mathrm{Re}(\mathrm{CO})_{3}\left(\mathrm{OH}_{2}\right)_{3}\right](\mathrm{Br})$ yielded the expected peptide conjugate as shown by HR-MS analysis. ${ }^{[45]}$

The click-then-chelate approach is also well suited when the organometallic entity does not withstand the conditions used in SPPS. An 0,0-chelating hydroxypyrone entity carrying an azido group 22 was coupled to [Leu ${ }^{5}$ ]-enkephalin carrying an terminal alkyne at its N-terminus. ${ }^{[46]}$ After deprotection / cleavage, metalation with $[\mathrm{Ru}(\mathrm{p}$ cym) $\left.\mathrm{Cl}_{2}\right]_{2}$ yielded a Ru-peptide conjugate whose structure was confirmed by top-down mass spectrometry. The Ru-enkephalin conjugate displayed significant cytotoxic activity in vitro on the human ovarian carcinoma cell line $\mathrm{CH} 1$ but no activity on colon and nonsmall lung cancer cells.

\subsubsection{Click-to-chelate strategy}

The click-to-chelate strategy differs from the two former approaches in that the generated 1,2,3-triazole linker becomes involved in metal coordination as a $\mathrm{N}$-donor within a tridentate ligand system. Consequently, CuAAC and metalation can be achieved simultaneously. ${ }^{[47]}$

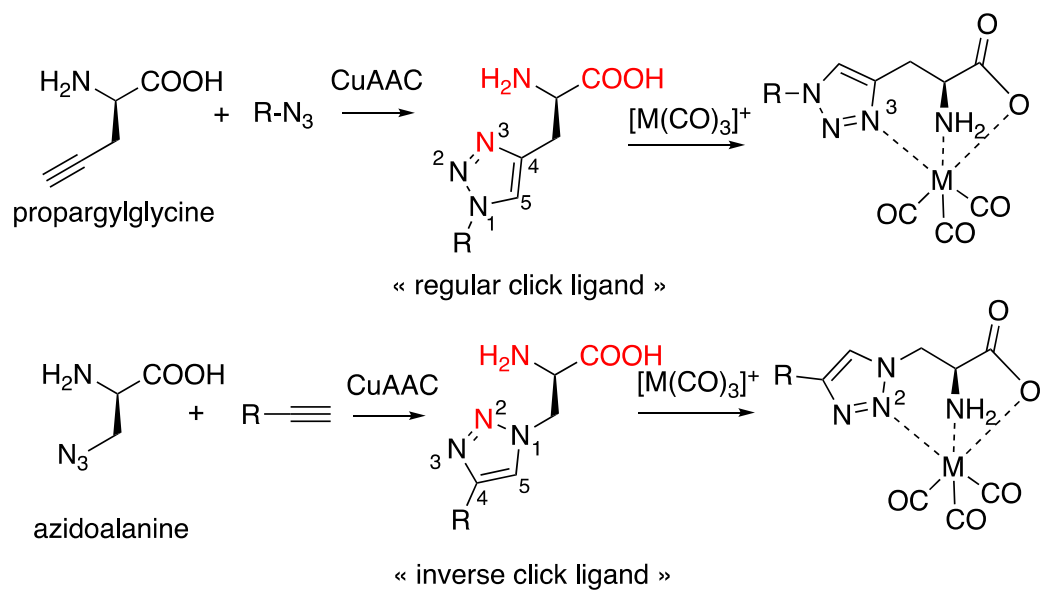

Scheme 3. Click-to-chelate approaches for the complexation of the $\left[\mathrm{M}(\mathrm{CO})_{3}\right]^{+}$core $(\mathrm{M}=$ Re, ${ }^{99 m} \mathrm{Tc}$ )

This ingenious concept was introduced by Mindt and Schibli in 2006 for the radiolabeling of an analogue of the biologically active peptide bombesin (BBS) with the $\gamma$-emitting radioisotope ${ }^{99 \mathrm{~m} T c .}{ }^{448]}$ BBS shows high affinity for the G-protein coupled gastrin-releasing peptide receptor (GRPR) which is overexpressed in a large number of tumors. Initially, two strategies were set up whether the azide or the alkyne partner is 
appended to the peptide at the $\alpha$-amino group at the $\mathrm{N}$-terminus of the peptide sequence. Click reaction with propargyl glycine or azidoalanine affords $\mathrm{N}, \mathrm{N}, \mathrm{O}$ tripodal ligands, called "regular click ligand" or "inverse click ligand", respectively providing a coordination site for $\left[\mathrm{M}(\mathrm{CO})_{3}\right]^{+}\left(\mathrm{M}=\mathrm{Re},{ }^{99 \mathrm{mTc})}\right.$ (scheme 3). It appeared that the "inverse click ligand" approach gave rise to lower metalation yields. Moreover, the radio-labeled peptide conjugates appeared to be unstable. In contrast, nearly quantitative metalation was achieved with the "regular click ligand" approach. Radiolabeled peptides were rapidly internalized in prostate cancer cells. Biodistribution studies in mice bearing tumor xenografts, showed that the glycated radiolabeled peptide was rapidly taken up in the colon and the pancreas in addition to the tumor and that accumulation was blocked by co-injection of unlabeled BBS. The same pathway was employed to radiolabel the peptide Lys-Cys-Cys-Tyr-Ser-Leu targeting the type 1 receptor tyrosine kinase ErbB2 which is overexpressed in a significant proportion of breast cancers. [49]

Alternatively, the "regular click ligand" was introduced within peptide sequences by reaction of propargylglycine from the $\varepsilon$-amino group of a lysine residue previously modified with azidoacetic acid. In this way, $99 \mathrm{~m}$ Tc-labeled conjugates derived from the peptides BBS and cMBP were prepared and shown to retain very good affinity for their respective membrane receptors GRPR and c-Met.

Mindt and co-workers introduced an alternative click-to-chelate approach where the tripodal chelating ligand includes two 1,2,3-triazoles and a primary amine (scheme 4).[50] The bis-alkyne, diprotected aminoacid 23 was appended at the N-terminal position of a modified BBS fragment by SPPS. CuAAC with azidoacetic acid afforded the bis-1,2,3-triazole motif which was subsequently used to chelate $\mathrm{Tc}(\mathrm{CO})_{3}$ to form a SPECT radiotracer targeting cells overexpressing GRPR. Biodistribution studies on PC-3 xenografts in mice showed high specific uptake in GRPR-positive pancreas, colon and tumor with renal excretion.

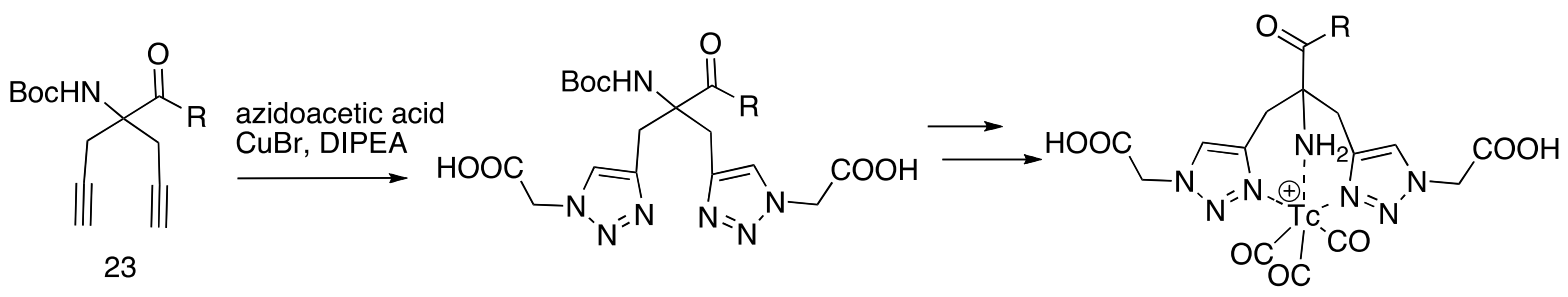

Scheme 4. Bis(triazole) ligand for the click-to-chelate approach

Although the organometallic entities conjugated via CuAAC to peptides / proteins sustained the reactional conditions required for the cycloaddition to take place, specially the presence of the $\mathrm{Cu}(\mathrm{I})$ catalyst, it may not be the case for other more sensitive organometallic complexes.

\subsection{Strained-promoted azide-alkyne cycloadditions (SPAAC)}

The requirement of cytotoxic copper catalyst limits the usage of $\mathrm{CuAAC}$ in biological contexts. One way to overcome this problem is to use strain-promoted azide-alkyne cycloaddition (SPAAC), developed by Bertozzi and co-workers (Table 1, entry 3).[51] SPAAC reactions rely on strained cyclooctyne derivatives that show a remarkably decreased activation energy in contrast to terminal alkynes, allowing [3+2] 1,3-dipolar cycloadditions with azides to take place at a reasonable rate in the absence of metal 
catalyst. Amongst the various bioorthogonal reactions, the SPAAC reaction is extensively used to study the dynamics of biological processes in vitro and in vivo. [52] Over the time an increasing number of reports has appeared in the literature on the bioconjugation of modified peptides and proteins with partner azide or cyclooctyne derivatives. However only few of them actually deal with organometallic transition metal complexes with azide or cyclooctyne-containing ligands. The number of applications of such metal complexes in biological studies is even more limited.

Lo and co-workers have reported highly emissive biscyclometalated iridium(III) ${ }^{[53]} 24$ and tricarbonyl rhenium(I) [54] 25 complexes functionalized with dibenzocyclooctyne (DBCO) unit as azide-reactive bioorthogonal handle. Reaction of the synthesized probes with BSA, HSA and apotransferrin (aTf) previously treated with azidoacetic acid, EDC and NHS was examined, and it was found that all the resulting bioconjugates inherited their emission properties from the conjugated organometallic entities (Figure 4).[53, 54] Furthermore imaging of $\mathrm{CHO}$ cells metabolically labeled with $\mathrm{N}$-azidoacetyl sialic acid and further treated with the Ir complex $\mathbf{2 4}$ or the Re complex 25 showed that fluorescence was mainly located in the cells plasmatic membrane.
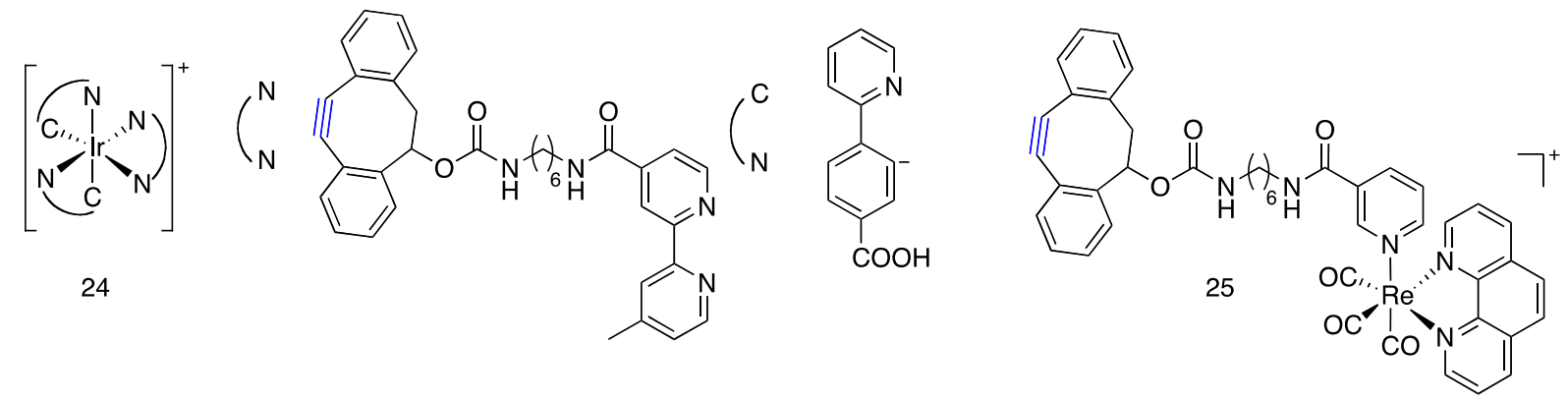

Figure 4. Biscyclometallated iridium(III) and tricarbonyl rhenium(I) complexes carrying a dibenzocyclooctyne (DBCO) handle.

As part of a study on artificial photosynthesis system, azide-functionalized Rh-based electron mediator 26 (Figure 5) was conjugated to formate dehydrogenase via SPAAC reaction. A double SPAAC reaction was performed with the homobifunctional crosslinker DBCO-PEG 4 -DBCO between $\mathbf{2 6}$ and formate dehydrogenase carrying a pazidophenylalanine residue at a permissive site. The obtained conjugate retained the ability to regenerate $\mathrm{NADH}$ either chemically in the presence of formate or photocatalytically in the presence of the photosensitizer eosin $\mathrm{Y}$ and a sacrificial electron donor.[55]

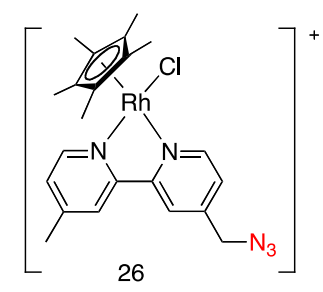

Figure 5. Azide-functionalised Rh-based electron mediator.

Application of SPAAC to the radiolabeling of HSA by the chelate-then-click approach was reported by Lee, Im and co-workers (Scheme 5).[56] In the first step, azide-functionalized 2,2'-dipicolylamine 27 was allowed to react with $\left[{ }^{99 \mathrm{~m} T c}(\mathrm{CO})_{3}\left(\mathrm{H}_{2} \mathrm{O}\right)_{3}\right]^{+}$to afford the 
$\left[(\mathrm{dpa})_{\mathrm{Tc}}(\mathrm{CO})_{3}\right]^{+}$complex, followed by SPAAC reaction with azadibenzocyclooctynefunctionalized HSA (ADIBO-HSA). Click conjugation efficiency was between 76 and 99\% depending on the number of ADIBO moieties attached to HSA. The obtained conjugate 99mTc-dpa-HSA showed significantly enhanced blood pool uptake compared to $99 \mathrm{mTc}$ HSA. The high stability of $99 \mathrm{mTc}$-dpa-HSA in vivo makes it a good candidate as potential blood pool imaging agent.[56]
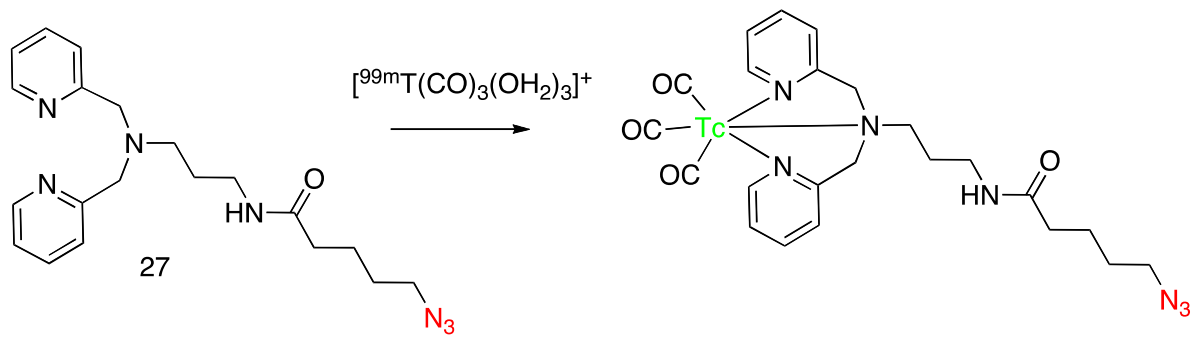

Scheme 5. Complexation of azide-functionalized 2,2'-dipicolylamine ligand by $\left[{ }^{99 \mathrm{~m} T c}(\mathrm{CO})_{3}\right]^{+}$(chelate-then-click labeling strategy by SPAAC).

Recently we have reported the synthesis of the Fp complex carrying an ADIBO handle 28 (Scheme 6).[33] Its reactivity was examined towards BSA and PAMAM dendrimer both carrying azide groups. Covalent coupling of $\mathbf{2 8}$ to azido modified macromolecules was assessed by IR spectroscopy. Although the SPAAC reaction works well, the metallocarbonyl motif was found to be unstable in the presence of the strained alkyne. ${ }^{33]}$ This finding exemplifies that the SPAAC strategy may not be compatible with all the organometallic entities, most likely owing to the intrinsic reactivity of strained alkynes towards nucleophiles.[57]

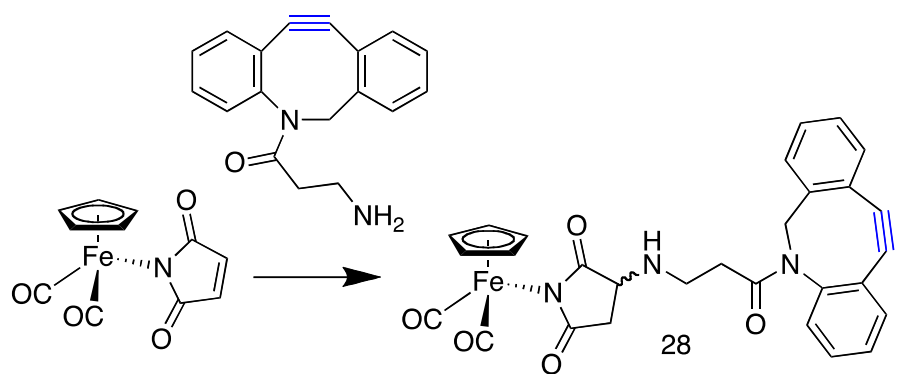

Scheme 6. Synthesis of Fp complex carrying a cyclooctyne handle.

\subsection{1,3-dipolar cycloadditions between alkynes and sydnone or nitrone}

Lo and co-workers described a series of luminescent transition metal complexes containing different bioorthogonal reactive groups able to target labeled biomolecules for imaging and therapeutic applications.[10] Among them, they investigated sydnone and nitrone moieties, to serve as both emission quenchers and dipole partners in metalfree cycloadditions with strained alkynes appended to proteins. Sydnones have recently been investigated as new cycloaddition partners of terminal or strained alkynes yielding substituted pyrazoles, after elimination of $\mathrm{CO}_{2}$ by retro Diels-Alder reaction, [58] while nitrones were only described in strain-promoted alkyne-nitrone cycloaddition (SPANC) reactions, affording isoxazoline derivatives (Table 1, entries 4 and 5).[59]

Lo and co-workers took advantage of emission quenching effects of sydnone and nitrone motifs for the design of new cyclometalated iridium (III) complexes with 
phosphorogenic properties to probe 1,3-cycloaddition reactions with strained alkyne derivatives. ${ }^{[60,61]}$ As expected, appended sydnone or nitrone units induced a decrease of emission intensity compared to sydnone-free or nitrone-free complexes depending on the substituents on the $\left(\mathrm{N}^{\wedge} \mathrm{C}^{-}\right)$ligand. Cycloaddition reactions of sydnone and nitrone complexes $\mathbf{2 9}$ and $\mathbf{3 0}$ were first validated with the model strained alkyne $(1 R, 8 S, 9 S)$ bicyclo[6.1.0]non-4-yn-9-yl)methanol (BCN-OH). Upon conversion to pyrazole or isoxazoline, complexes recovered their luminescent properties, with higher emission enhancements observed with nitrone complexes $\left(I / I_{0}=60.5\right.$ for 30b compared to 7.9 for 29b, and 135.0 for 30c compared to 2.5 for 29c). These complexes were then reacted with model BCN-modified proteins (bovine serum albumin (BSA), human serum albumin (HSA) and holo-transferrin (HTf)) in order to explore their bioorthogonal labeling abilities and photophysical properties (Scheme 7). Again, luminescent properties were turned-on when reacted with $\mathrm{BCN}$-modified proteins, while emission intensities remained low when incubated with unmodified protein, showing the orthogonality of the dipole partners. Again more pronounced enhancement effects were observed with nitrone than sydnone complexes $\left(I / I_{0}=292.8\right.$ for 30b compared to 24.9 29b, and 618.0 for 30c compared to 5.2 for 29c, with BCN-BSA). Furthermore, emission enhancements are higher with $\mathrm{BCN}$-modified proteins than with $\mathrm{BCN}-\mathrm{OH}$, which is attributed to increased hydrophobicity and rigidity brought by the protein in the proximal environment of cyclometalated iridium (III) polypyridine complexes,[61-63] and this behavior is an additional asset when developing bioorthogonal imaging agents.
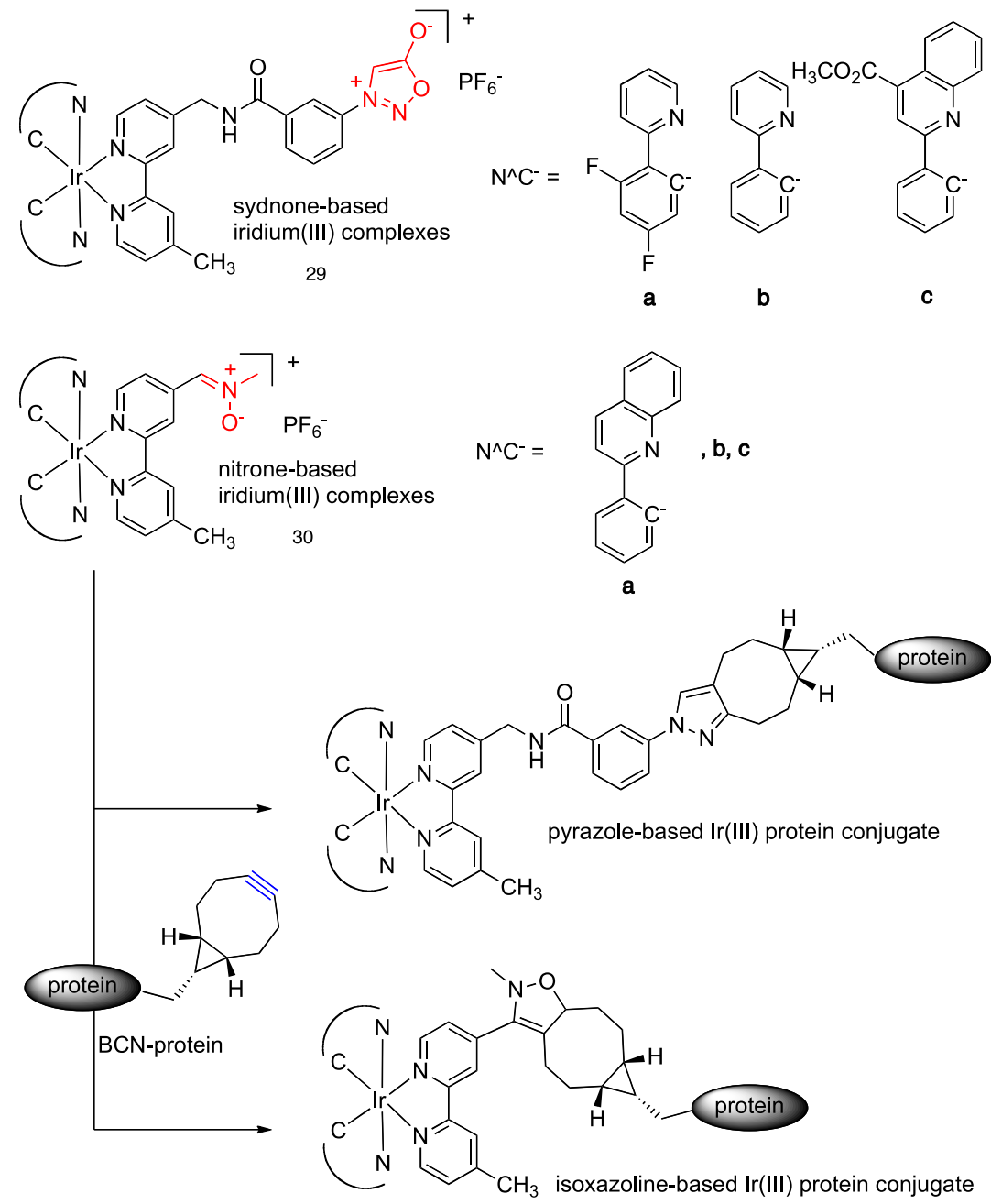
Scheme 7. Structures of phosphorogenic sydnone-based and nitrone-based cyclometalated iridium(III) polypyridine complexes and strained-promoted sydnone/nitrone-alkyne cycloaddition reactions with proteins (BSA, HSA, HTf) modified with orthogonal BCN handle to afford luminescent conjugates for imaging applications. $[60,61]$

\subsection{Photoclick 1,3-dipolar cycloaddition}

Gasser and co-workers tried a metal-free 1,3-dipolar cycloaddition between a nitrile imine generated by mild photoactivation of a tetrazole, and an alkene (scheme 8),[64] coined photoclick, to append two organometallic probes, namely IR-active cymantrene and redox-active ferrocene to molecules with biological activities, to extend their properties.[65]

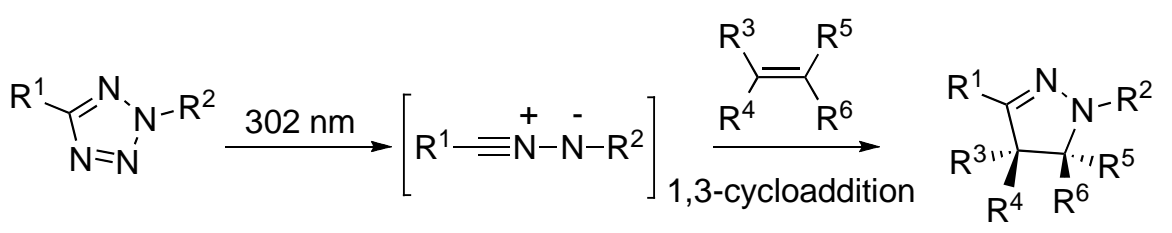

Scheme 8. Principle of photoclick 1,3-dipolar cycloaddition.

They investigated the labelling of a tetrapeptide derivative known as nuclear localization signal (NLS), able to target cell nucleus ${ }^{[66]}$ and a PNA sequence, described as antisense agent inhibiting hepatitis $B$ virus reverse transcription. [67] They introduced the tetrazole moiety into the peptide or the PNA sequence by SPPS using acid $\mathbf{3 1}$ to yield orthogonal partners NLS-tetrazole and PNA-tetrazole (figure 6).[65] These compounds were then reacted with maleimide-modified cymantrene $\mathbf{3 2}$ and/or ferrocene $\mathbf{3 3}$ upon $302 \mathrm{~nm}$ light irradiation at room temperature. It appeared that cymantrene was not the optimal organometallic candidate since the main product of the photoclick cycloaddition with NLS- tetrazole was the byproduct $\mathbf{3 4}$ arising from hydrolysis of the cycloadduct and concomitant decomposition of $\mathrm{Mn}(\mathrm{CO})_{3}$ moiety, known to be unstable upon light irradiation. With ferrocene derivative, expected NLS-pyrazoline-ferrocene conjugate 35 was obtained in $20 \%$ yield after optimization, while the photoclick performed with PNA-tetrazole afforded a mixture of four compounds including the expected photoclick product 36 in $6.5 \%$ yield, the doubly Fc labeled product 37 resulting from photoclick and Michael addition of the cysteine onto the maleimide double bond in $8 \%$ yield, the mono hydrolysed product 38 in $14 \%$ yield, and the unlabeled hydrolysed product 39 as the main compound (30\% yield). The yield of the photoclick compound $\mathbf{3 6}$ was not greater than $10 \%$ after optimization. Eventually, this photoclick reaction seems unsuitable for the labelling of organometallic moieties, whatever their light sensitivity. 

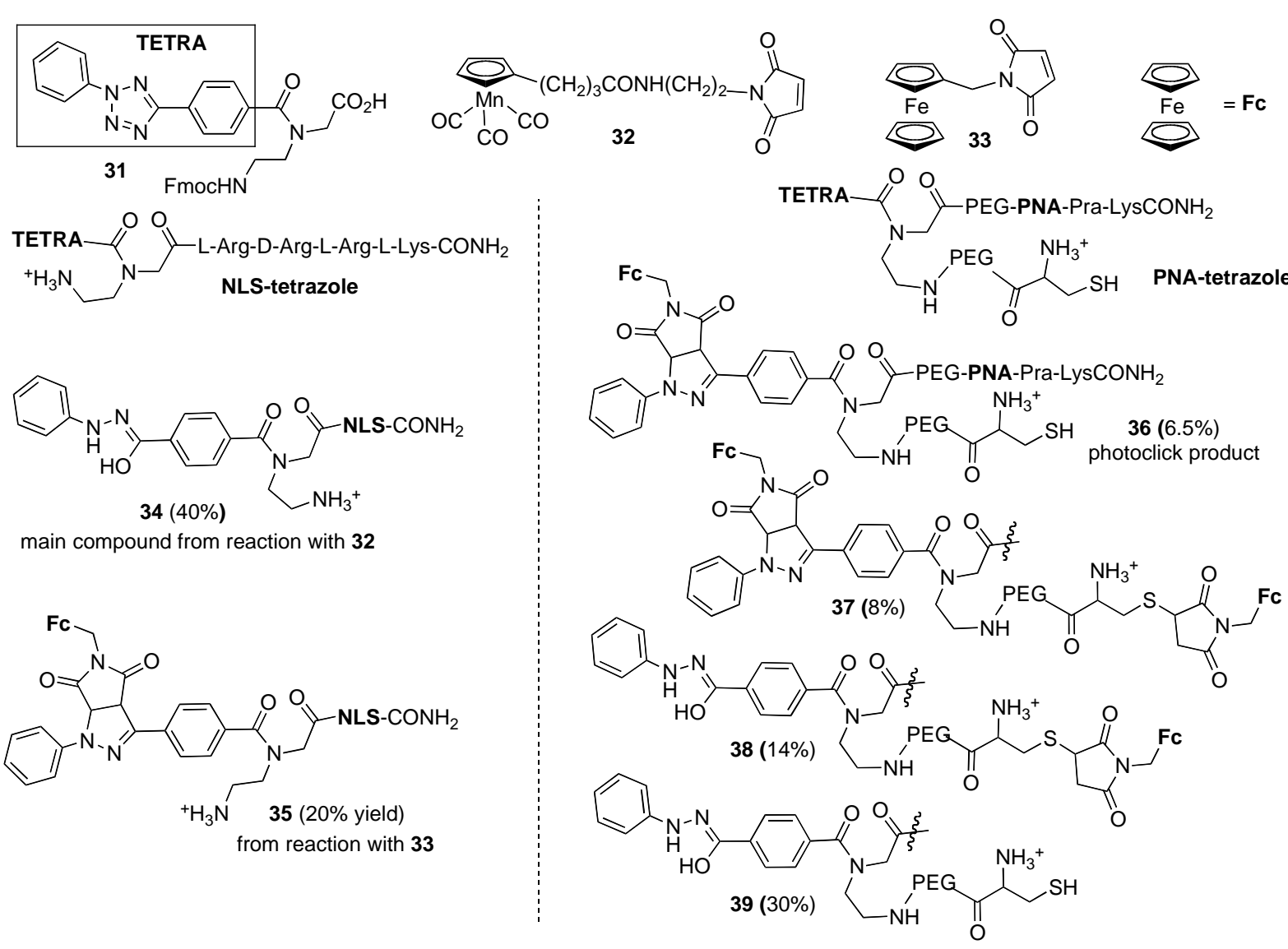

main compound from reaction with $\mathbf{3 2}$

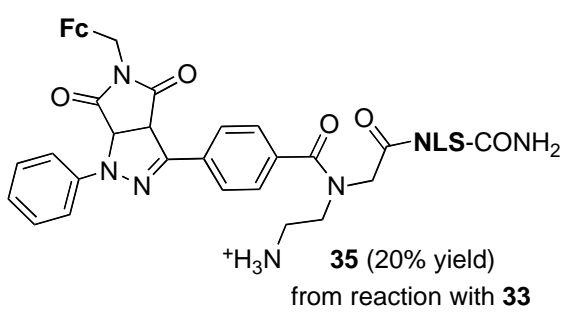

Figure 6. Structure of tetrazole derivative $\mathbf{3 1}$ used to prepare NLS-tetrazole and PNAtetrazole. Structures of maleimide-modified cymantrene $\mathbf{3 2}$ and ferrocene $\mathbf{3 3}$ as orthogonal partners. Structures of isolated compounds after their reaction with NLStetrazole and/or PNA-tetrazole. Adapted from ref. [65]. Copyright 2016 with permission from The Royal Society of Chemistry.

\section{Inverse electron-demand Diels-Alder (iEDDA) cycloaddition}

One of the most promising bioorthogonal conjugation methods is the inverse electrondemand Diels-Alder (iEDDA) reaction between 1,2,4,5-tetrazines and alkenes or alkynes (Table 1, entry 6). The "tetrazine ligation" attracted much attention because of fast reaction kinetics, high selectivity and high compatibility with water. ${ }^{[68]}$ Mechanistically, the iEDDA reaction proceeds via [4+2] cycloaddition between electron-rich or strained alkenes and tetrazines, followed by a retro-Diels-Alder reaction to release $\mathrm{N}_{2}$ and prototropic rearrangement to afford 1,4-dihydropyridazines as a mixture of isomers (Scheme 9). Alternatively, iEDDA reactions between tetrazines and strained alkynes afford pyridazine products (Scheme 9). 


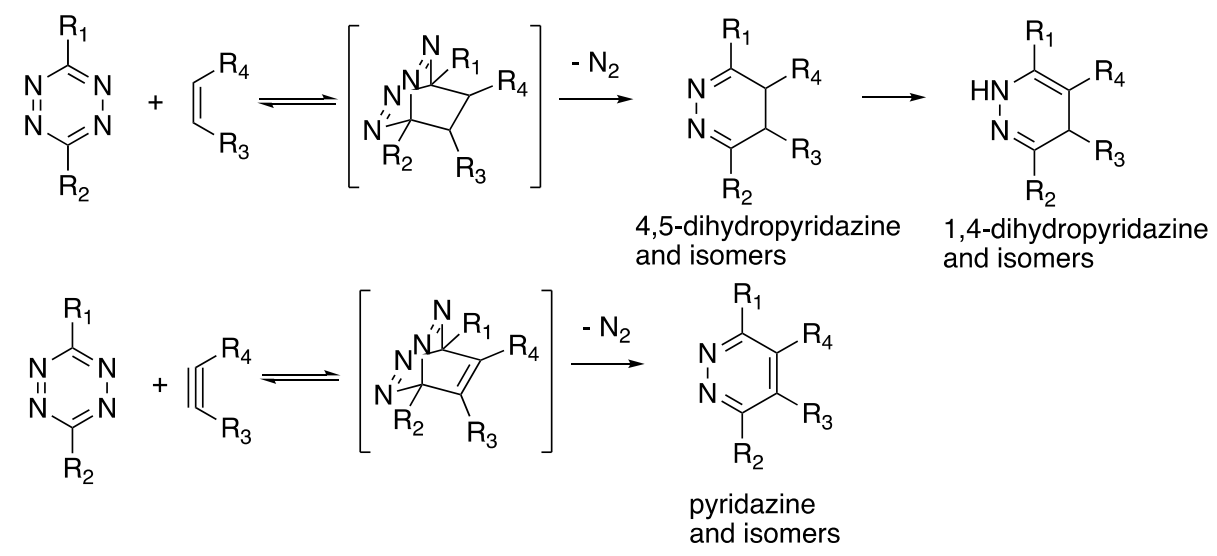

Scheme 9. iEDDA reaction between tetrazine and alkene or alkyne

Besides this, tetrazine derivatives exhibit emission quenching properties due to Föster resonance energy transfer (FRET) mechanism that no longer occurs after formation of non-quenching dihydropyridazines. ${ }^{[69]}$ All these features make iEDDA useful for biological labeling and imaging of live cells. ${ }^{[70]}$

Although there are many studies on iEDDA reaction, those dealing with transition metal complexes remain limited. Lo and co-workers reported that a series of mononuclear and dinuclear rhenium(I) tricarbonyl complexes incorporating a tetrazine moiety formed a new class of phosphorogenic probes reacting with dienophile-labeled biomolecules.[71] The complexes were firstly tested in reaction with model alkene and alkyne derivatives to give the expected dihydropyridazine and pyridazine products with enhanced phosphorescence emission. BCN-modified proteins were also successfully labeled with the binuclear rhenium complex $\mathbf{4 0}$ (Figure 7) and the resulting conjugates displayed strong phosphorescence upon excitation.

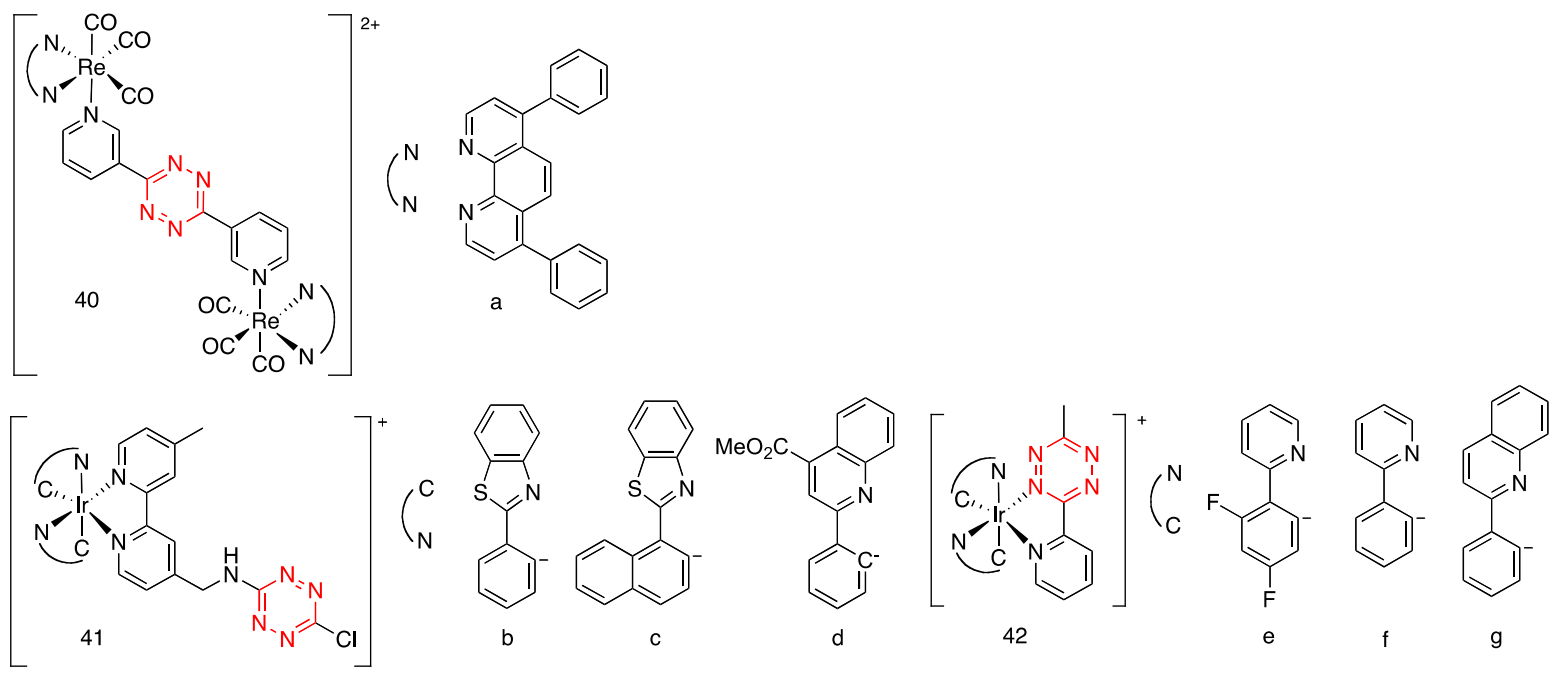

Figure 7. Structure of transition organometallic complexes for iEDDA.

In another study, BCN-modified BSA was bioorthogonally labeled with phosphorogenic tetrazine labels derived from cyclometalated iridium(III) complexes 41. [62] The emission of these complexes was efficiently quenched by FRET and /or PET process and turned on while the reaction of BCN-BSA occurred with extremely large emission enhancement factors. Complex $\mathbf{4 1}$ was applied to image azide-modified $N$-glycans in live cells. 
Labeling was achieved by a two-step procedure: a bis-BCN homobifunctional cross linker was reacted with azido-modified $N$-glycans, followed by reaction with complex 41. ${ }^{[62]}$

An even smarter example reported by the same group concerns the labeling of biomolecules by iridium(III) pyridyl-tetrazine complexes 42. In this study, the tetrazine unit serves as the chemical reporter group which easily reacts with alkene or alkyne but also as the luminophore because of the strong emission upon the iEDDA reaction. Lo and coworkers designed three complexes 42e-g with luminogenic bioorthogonal labeling properties where the pyridyl-tetrazine unit is coordinated to the metal center (Figure 7). The incorporation of the electron-deficient tetrazine ligand to the iridium complex provides very weakly emissive compounds. The bioorthogonal reaction of these compounds with cyclooctyne derivatives caused very strong emission as a result of the conversion of coordinated tetrazine unit into a pyridazine derivative. Reaction with BSA carrying BCN entities gave rise to even stronger emission than observed for the reaction with BCN-OH itself. The depicted strategy was further applied to label a GST-HaloTag fusion protein alone and expressed in HeLa cells (Scheme 10).[63]

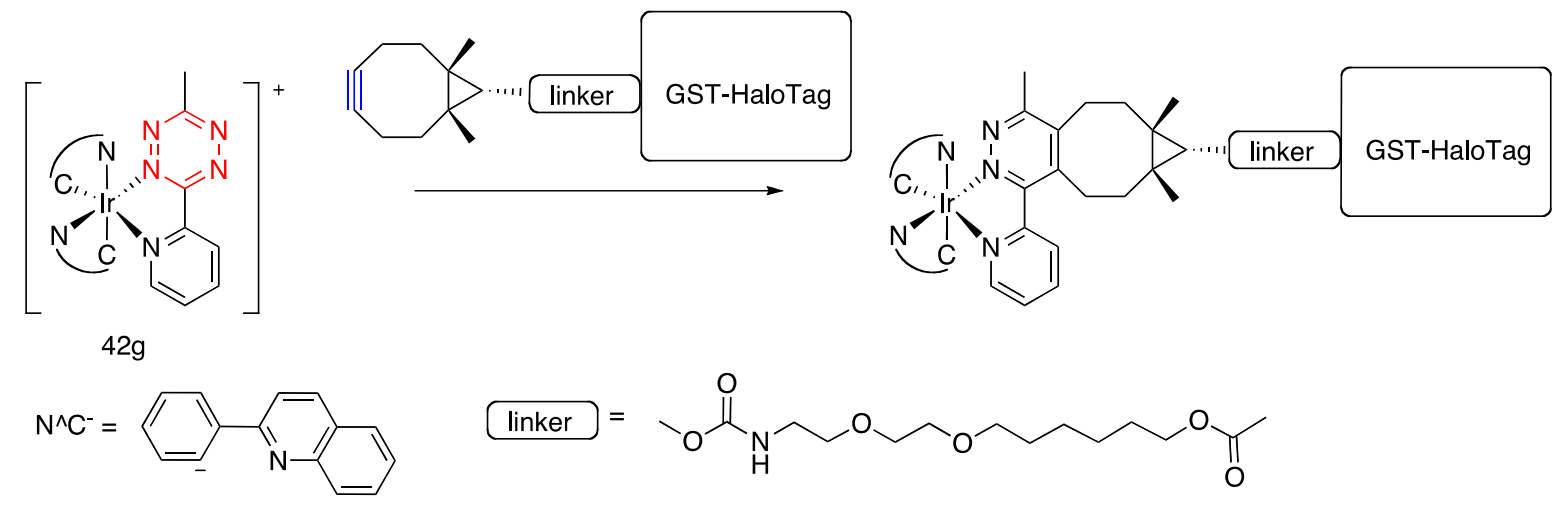

Scheme 10. Bioorthogonal reaction of BCN modified GST-HaloTag with pyridyl-tetrazine iridium complex $\mathbf{4 2 g}$.

All the examples reported so far involved complexes carrying the tetrazine handle while the protein carried the strained alkyne partner. The challenge is now to develop reverse reactions.

\section{Polar reactions}

\subsection{Sonogashira cross-coupling}

Palladium-mediated Sonogashira cross-coupling[72] between terminal alkyne and aromatic halide (Table 1, entry 7) was reported to install organometallic moieties onto biologically relevant peptides, either by incorporating the unnatural amino acid 4-iodophenylalanine in place of phenylalanine, or 4 -iodobenzoic acid at the $\mathrm{N}$-terminus. These modified peptide sequences were obtained by SPPS followed by cleavage from the solid support before performing the Sonogashira cross-coupling.

After their pioneering work demonstrating the Pd-catalyzed coupling of C-terminus alkynyl amino acids and a tripeptide with ferrocenyl iodoarene ${ }^{[73]}$ or, conversely, alkynyl ferrocene derivative and iodobenzene amino acids,[74] Metzler-Nolte and coworkers described the conjugation of the alkynyl ferrocene derivative $\mathbf{1 6}$ to p- 


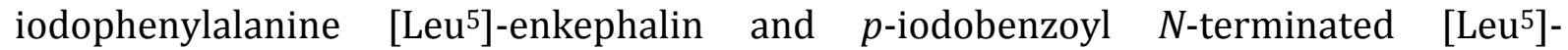
enkephalin (scheme 11).[75] Pd-catalyzed coupling proceeded in DMF/ NEt 3 (1:1) due to solubility problems and organometallic peptides $\mathbf{4 3}$ and $\mathbf{4 4}$ were obtained in 47.6 and $22.5 \%$ yield respectively, after purification by preparative HPLC. The electroactive properties of the ferrocene label, evaluated by cyclic voltammetry and square wave voltammetry, can serve to detect such biomolecules using techniques such as HPLC with electrochemical detection (HPLC-ECD).[75, 76]

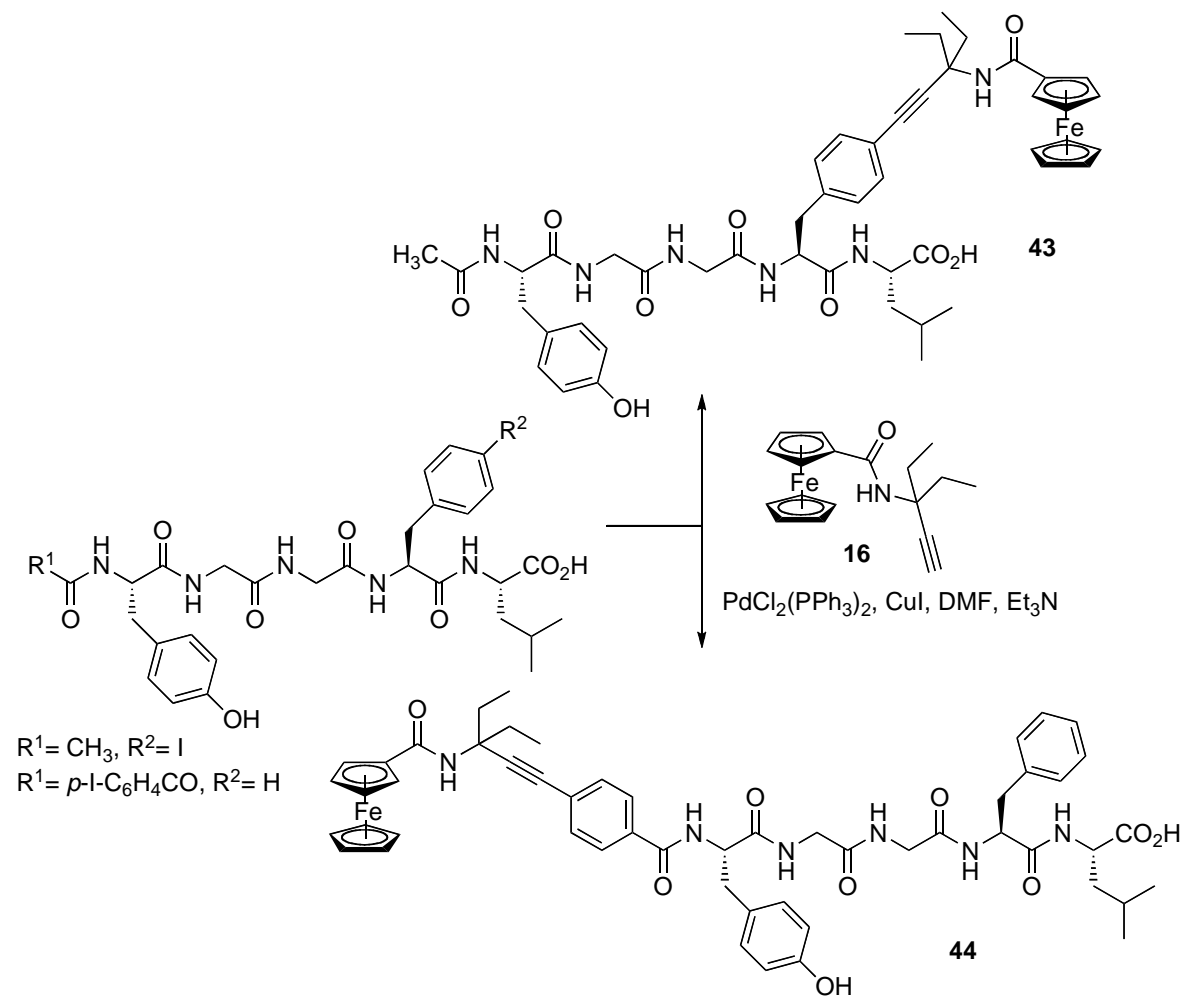

Scheme 11. Synthesis of ferrocene-[Leu $\left.{ }^{5}\right]$-enkephalin conjugates via Sonogashira crosscoupling. Adapted from ref. [75]. Copyright 2006 with permission from American Chemical Society. [75]

Another example of Sonogashira cross-coupling was reported in the field of CORMs. Schatzschneider and co-workers reported the synthesis of conjugates of Thr-Phe-SerAsp bearing a photoactivatable CORM based on tricarbonyl manganese(I) complex coordinated to the tpm ligand. ${ }^{[20]}$ The modified peptide sequences were obtained by SPPS by incorporating the same iodoarene derivatives (4-iodo-phenylalanine within the peptide sequence or 4 -iodobenzoic acid at the $N$-terminus), again in DMF/ $\mathrm{NEt}_{3}$ (1:1). After cleavage from the solid support, these peptides were orthogonally conjugated to the propargyl ether of the tpm-manganese tricarbonyl moiety 2 via Sonogashira crosscoupling (scheme 12). Peptide with $\mathrm{N}$-terminal iodoarene gave conjugate 45 in moderate yield (48\%) but in high purity (98\%), whereas peptide with 4-iodophenylalanine side chain led to conjugate 46 in better yield (62\%) but slightly lower purity (91\%). 


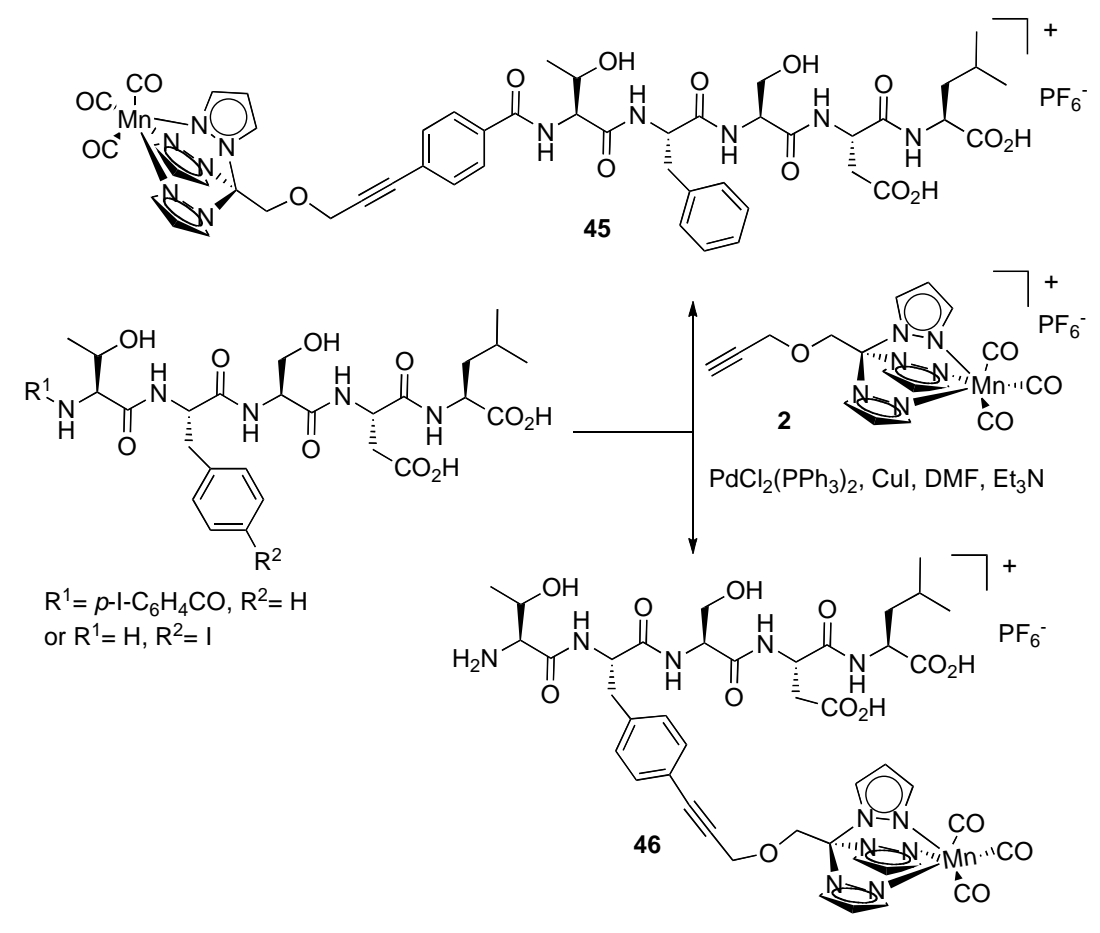

Scheme 12 . Synthesis of $\left[\mathrm{Mn}(\mathrm{CO})_{3}(\mathrm{tpm})\right]^{+}$-peptide conjugates via Sonogashira crosscoupling. Adapted from ref. [20]. Copyright 2009 with permission from The Royal Society of Chemistry.

Conversely to the previous examples when the Sonogashira coupling reaction was performed after cleavage from the solid support, the next one exploited the reaction onsupport in the field of oligodeoxynucleotides (ODNs) labeling. Grinstaff and co-workers described the first on-column site-selective derivatization of halo-substituted nucleobases with alkyne-terminated ferrocene derivative (ferrocenoyl propargylamide 47) in combination with standard automated DNA synthesis.[77, 78] Ferrocene was chosen for its redox and spectroscopic properties that could be used to develop DNA diagnostic technologies and to study DNA-mediated charge transfer. Halonucleoside phosphoramidite precursors, 2'-deoxy-5-iodouridine or 2'-deoxy-8-bromoadenosine, were incorporated at the desired position on the ODN through standard automated DNA synthesis. The procedure implies to remove the column from the synthesizer and to dry by flushing with argon or nitrogen before filling with DMF/ $\mathrm{NEt}_{3}$ (9:1) to perform the Sonogashira cross-coupling in sealed column for $6 \mathrm{~h}$. The column was then rinsed with DMF- $\mathrm{NEt}_{3}$ and $\mathrm{CH}_{3} \mathrm{CN}$, dried and replaced on the synthesizer to continue the oligonucleotide synthesis (Scheme 13). This method afforded labelled ODNs with up to $50 \%$ yield after HPLC purification. ${ }^{[77]}$ Ferrocene-uridine phosphoramidite $\mathbf{4 8}$ was also prepared off-column and incorporated in oligodeoxynucleotides by standard automated DNA synthesis to compare the two methods. The on-column procedure was found to be more suitable for the synthesis of ferrocene-labeled ODNs which were obtained with higher yields.[78] In term of stability of labeled duplexes, thermal denaturation experiments showed that modification of uridine with ferrocene has little influence on the duplex stability contrary to the modification of adenosine that induces disruption of duplex structure to some extent. 


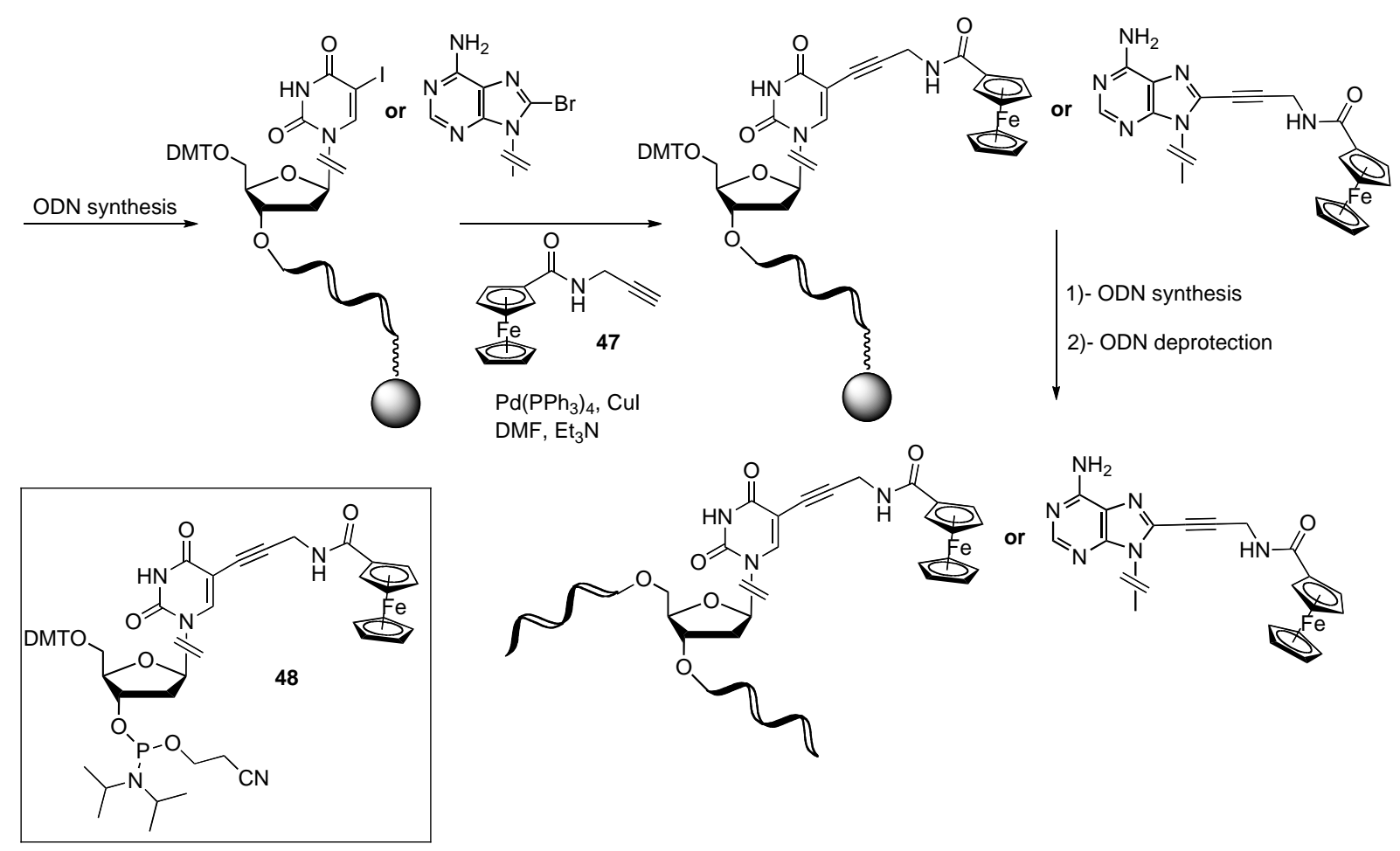

Scheme 13. On-column Sonogashira cross-coupling for the labelling of ODNs with ferrocenoyl propargylamide $\mathbf{4 7}$ in combination with standard automated ODN synthesis. Insert: ferrocene-uridine phosphoramidite $\mathbf{4 8}$ used for standard ODN synthesis to compare the procedures. ${ }^{[77,78]}$

Although these three examples exploit reactive functions that are not naturally occurring in biological molecules, they all perform in DMF/NEt ${ }_{3}$ for solubility reasons, conditions that are not exactly bioorthogonal since they do not operate in physiological media. Truly bioorthogonal Sonogashira cross-coupling reactions were reported in 2007 in the field of protein labeling in aqueous medium with copper salt and additives, but in low yield,[79] and improved yields were later reported with the development of new water-soluble palladium complexes allowing copper-free carbon-carbon bond formation inside bacterial cells.[80] But none of these examples involve the conjugation of organometallic complexes.

\subsection{Carbonyl ligation techniques}

Older ligation techniques exploiting the orthogonal carbonyl group as chemical reporter are still widely used to react with functional groups that are not naturally occurring in biomolecules such as oxyamines and hydrazides to form oximes and hydrazones respectively (Table 1, entries 8 and 9).[81] Carbonyl reporter groups can be appended to biomolecules by different techniques, such as mild oxidation of glycoproteins, $\mathrm{N}$ terminal serine or threonine, site specific incorporation of unnatural amino acids by the biosynthetic pathway ${ }^{[82]}$ or genetic encoding of specific nucleotides sequence expressing formylglycine-containing proteins, ${ }^{[83]}$ to name a few.

\subsubsection{Hydrazone ligation}

We are involved in the site-specific labeling of antibodies (immunoglobulins G or IgG) with multiple copies of transition metal carbonyl complexes for use as new universal 
detection reagents in a modified solid-phase format of the carbonyl metallo immunoassay (CMIA) we introduced in the early 1990s. ${ }^{[84]}$ CMIA takes advantage of the specific and intense vibration bands owing to CO ligands $\left(v_{\mathrm{CO}}\right)$ in the mid-infrared (IR) spectral range allowing their quantification by measuring the height of the $v_{\text {co }}$ bands. As the height is proportional to the quantity of metal carbonyl complex (IR probe), the more metal carbonyl moieties are attached to the antibody, the higher the resulting IR signal is. Consequently, tiny quantities of antibody could be detected if labeled with numerous copies of IR probes. In this objective, (polyamido)amine (PAMAM) dendrimers[85] seemed ideal carriers to covalently couple multiple IR probes to antibodies. ${ }^{[86]}$ Indeed these synthetic biopolymers are available in a variety of sizes (termed generations) and terminal reactive groups (amines, alcohols, carboxylic acids) for further chemical modifications and are soluble in aqueous medium. These features have made them popular for biomedical applications. ${ }^{[87]}$ We worked with generation 4 (G4), which has 64 theoretical amine end groups. PAMAM-G4 was functionalized with 22 to $29 \mathrm{Fp}$ units and 4 to 5 hydrazide groups by reaction of complex 49 and heterobifunctional linker carrying an nitroaniline NMR probe 50, respectively (Scheme 14).[88] IgGs are glycoproteins with carbohydrate moieties located in the Fc region, far from the antigen binding sites. Consequently these carbohydrates are ideal targets for site-selective and orthogonal conjugation to hydrazide-functionalized compounds after mild oxidation to generate carbonyl reactive groups. Using this strategy, we were able to orthogonally conjugate 1.0 to 1.5 dendrimer carrying Fp units per antibody, depending on the dendrimer sample (Scheme 15), corresponding to the loading of $30 \mathrm{Fp}$ probes on average per antibody. Hydrazone linkages were stabilized by reduction with $\mathrm{NaBH}_{3} \mathrm{CN}$ before further evaluation as detection reagent in solid-phase CMIA. As a proof of concept, Fp-labeled goat anti-rabbit IgG antibody was evaluated to quantify known quantities of rabbit IgG spotted onto nitrocellulose membranes in the range 1.3-266.7 pmol by IR spectroscopy (Figure 8).

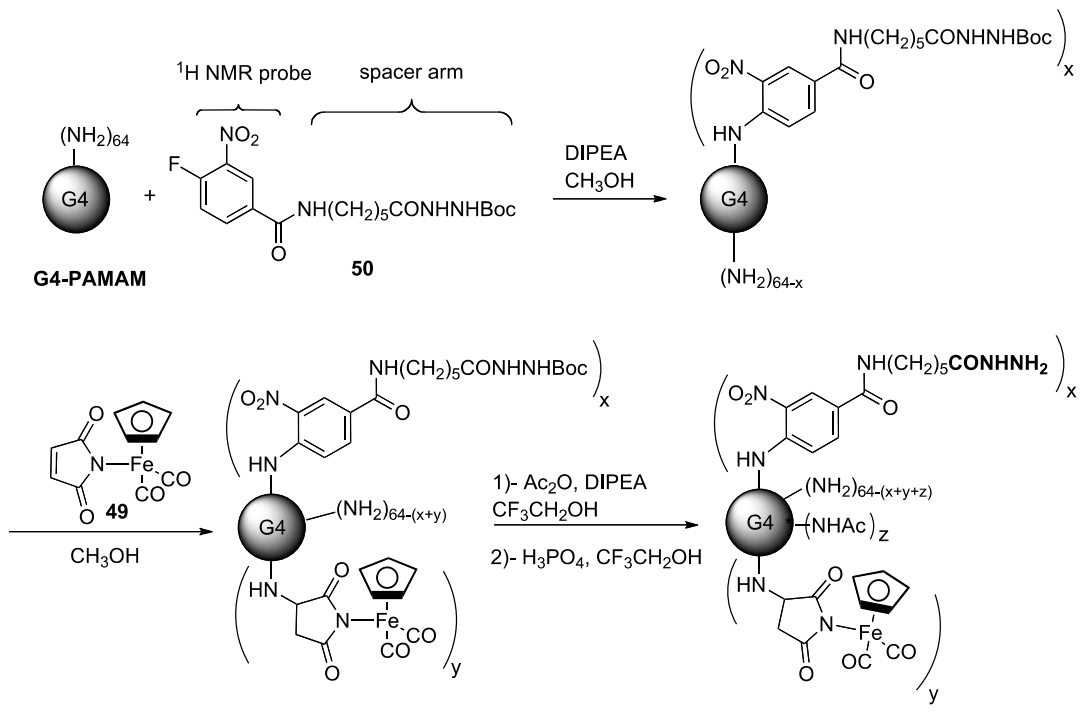

Scheme 14. Synthetic route to hydrazide-based metal carbonyl PAMAM-G4 dendrimers. Adapted from ref. [88]. Copyright 2010 with permission from Elsevier. 


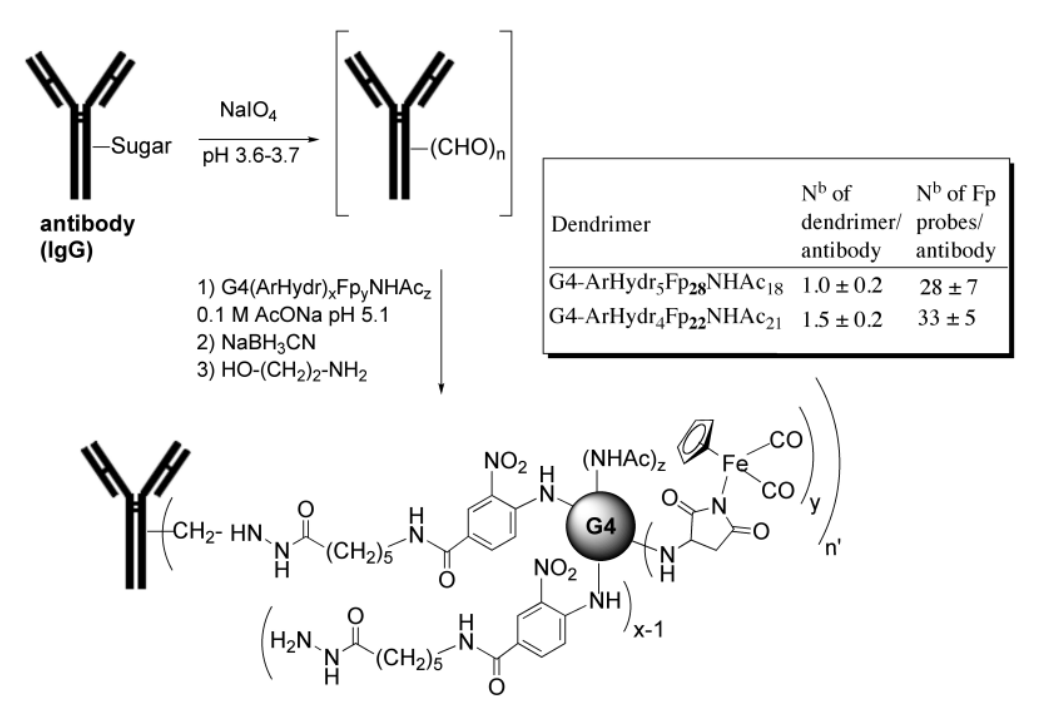

Scheme 15. Synthetic route to IgG-dendrimer conjugate by orthogonal ligation. Adapted from ref. [88]. Copyright 2010 with permission from Elsevier.
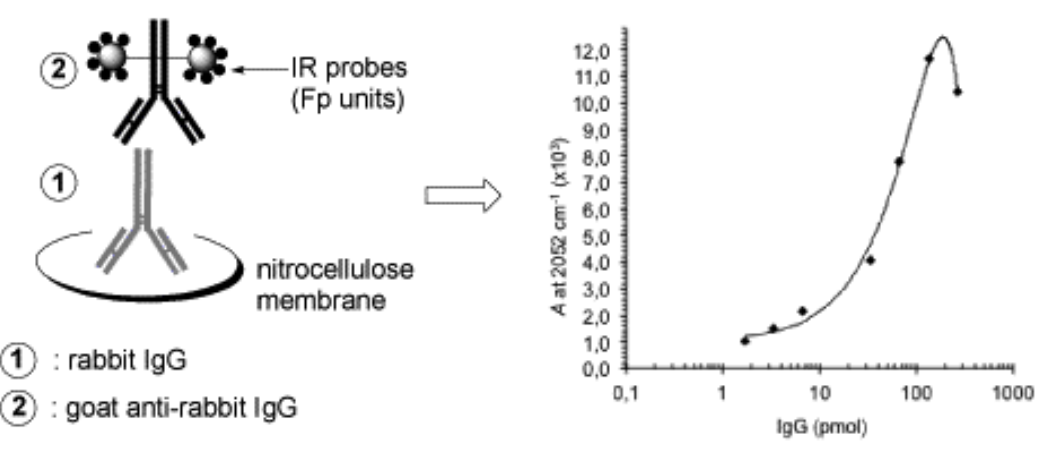

Figure 8. Schematic antigen-antibody interaction between rabbit IgG (antigen) and goat anti-rabbit IgG carrying IR probes (antibody) at the membrane surface and quantification of rabbit IgG spotted onto nitrocellulose membranes (in the range 1.3$266.7 \mathrm{pmol})$ incubated with an excess of Fp-labeled goat anti-rabbit IgG ( $0.3 \mathrm{nmol}$ per assay). IR measurements were done in the transmission mode on dried membranes. Reproduced from ref. [88]. Copyright 2010 with permission from Elsevier.

\subsection{Oxime ligation}

Schatzschneider and co-workers described the synthesis of a peptide-photoCORM conjugate by oxime ligation. ${ }^{[89]}$ The TGF- $\beta$ peptide sequence was used as the carrier part of the conjugate to deliver photoactivated carbon monoxide from the photoCORM tricarbonylmanganese(I) complex coordinated to the 2,2-bis(pyrazolyl)ethylamine (bpea) ligand. Here, the aldehyde group was appended to the complex by reductive amination between 4-(diethoxymethyl)benzaldehyde and bpea by followed by hydrolysis of the acetal protective group, and reaction with $\mathrm{Mn}(\mathrm{CO})_{5} \mathrm{Br}$ to afford the aldehyde-functionalized photoCORM 51. The peptide sequence was obtained by SPPS, then $N$-terminal functionalization to attach the orthogonal aminoxy handle was carried out with (aminoxy)acetic acid. After cleavage from the solid support, the aminoxypeptide 52 was conjugated to the aldehyde-functionalized photoCORM $\mathbf{5 1}$ under mild and catalyst-free conditions to afford peptide-photoCORM conjugate $\mathbf{5 3}$ (Scheme 16) in 
moderate yield (58\%) but in high purity (98\%). This conjugate proved to be stable in pure water for 4 days in the dark. The myoglobin assay indicated that ca. 2 equiv. of $\mathrm{CO}$ were released per conjugate $\mathbf{5 3}$ upon irradiation at $365 \mathrm{~nm}$.

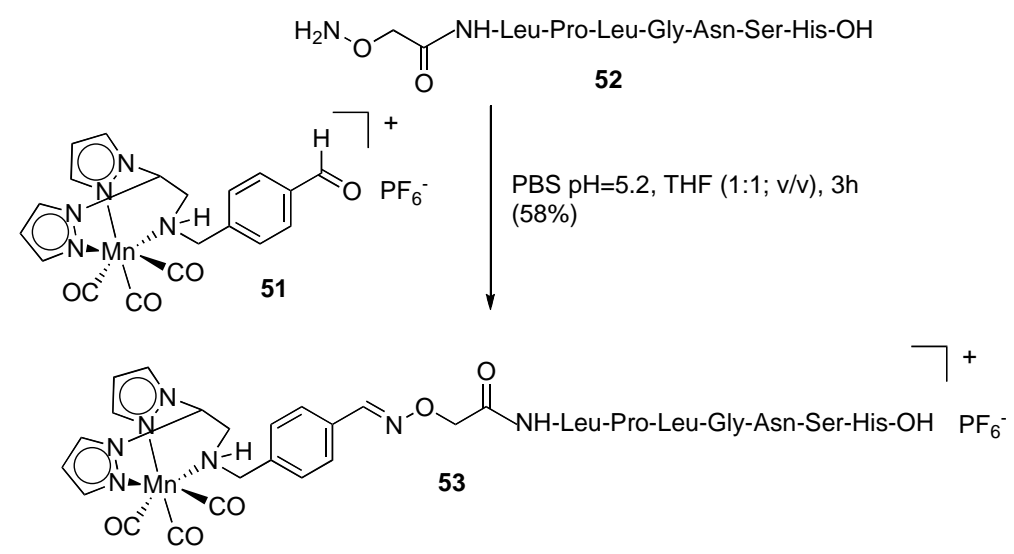

Scheme 16. Synthesis of $\left[\mathrm{Mn}(\mathrm{CO})_{3}(\text { bpea })\right]^{+}$-peptide conjugate 53 via oxime ligation. Adapted from ref. [89]. Copyright 2014 with permission from Wiley-VCH.

The selectivity of the carbonyl ligation reactions is controlled by the $\mathrm{pH}$ of the reaction medium which should be slightly acidic to prevent side reactions with the amines of proteins. Consequently, this requirement precludes to apply these bioconjugation reactions inside cells. ${ }^{[57]}$

\section{Conclusions and perspectives}

To summarize, a large variety of bioorthogonal ligation methods has now been implemented to introduce transition organometallic complexes onto biologically active peptides, proteins, and peptide-like oligomers, taking benefit from the high chemoselectivity of this family of chemical reactions. Let us note however that most of the examples reported in the literature so far have been dealing with reactions in organic solvents on pure molecules and that bioorthogonal reactions involving organometallic complexes in biological settings are still rare. Moreover, bioconjugation of organometallic complexes has essentially been done to take advantage of their optical, electrochemical or radio-emitting properties, much less often for their therapeutic properties and never for their catalytic properties. Consequently, this still provides numerous opportunities for bioorganometallics to take a larger space in the ever growing area of chemical biology.

Supporting information: sequences of peptides used in bioorthogonal ligations with organometallic complexes; structures of ligands for $\mathrm{CuAAC}$

\section{Acknowledgement}

The work was financially supported by Sorbonne Université and CNRS, France and the University of Lodz, Faculty of Chemistry, Poland. 


\section{Graphical Abstract}

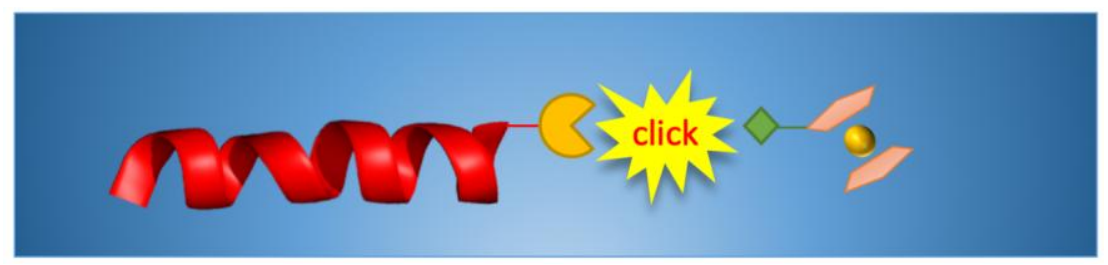

The recent developments in bioorthogonal ligations of transition organometallic complexes to peptides and proteins and their application in fluorescence or radioisotopic imaging and targeted delivery of pharmaceutical agents are reviewed

\section{References}

[1] E. M. Sletten, C. R. Bertozzi, Angew. Chem. Int. Ed. 2009, 48, 6974-6998; O. Boutureira, G. J. L. Bernardes, Chem. Rev. 2015, 115, 2174-2195.

[2] M. F. Debets, J. C. M. van Hest, F. P. J. T. Rutjes, Org. Biomol. Chem. 2013, 11, 64396455.

[3] H.-W. Shih, D. N. Kamber, J. A. Prescher, Curr. Opin. Chem. Biol. 2014, 21, 103-111; D. M. Patterson, L. A. Nazarova, J. A. Prescher, ACS Chem. Biol. 2014, 9, 592-605.

[4] N. K. Devaraj, ACS Central Sci. 2018, 4, 952-959.

[5] M. Grammel, H. C. Hang, Nature Chem. Biol. 2013, 9, 475-484.

[6] T. Cañeque, S. Müller, R. Rodriguez, Nature Rev. Chem. 2018, 2, 202-215.

[7] L. I. Willems, W. A. Van der Linden, N. Li, K.-Y. Li, N. Liu, S. Hoogendoorn, G. A. Van der Marel, B. I. Florea, H. S. Overkleeft, Acc. Chem. Res. 2011, 44, 718-729.

[8] K. S. Yang, G. Budin, C. Tassa, O. Kister, R. Weissleder, Angew. Chem. Int. Ed. 2013, 52, 10593-10597.

[9] G. Jaouen, Bioorganometallics. Biomolecules, Labeling, Medicine, Wiley-VCH, Weinheim, 2006.

[10] A. M.-H. Yip, K. K.-W. Lo, Coord. Chem. Rev. 2018, 361, 138-163.

[11] T. U. Connell, P. S. Donnelly, Coord. Chem. Rev. 2018, 375, 267-284.

[12] J.-P. Meyer, P. Adumeau, J. S. Lewis, B. M. Zeglis, Bioconjugate Chem. 2016, 27, 2791-2807.

[13] B. Albada, N. Metzler-Nolte, Chem. Rev. 2016, 116, 11797-11839; B. Albada, N. Metzler-Nolte, Acc. Chem. Res. 2017, 50, 2510-2518.

[14] F. Schwizer, Y. Okamoto, T. Heinisch, Y. Gu, M. M. Pellizzoni, V. Lebrun, R. Reuter, V. Kohler, J. C. Lewis, T. R. Ward, Chemical Reviews 2018, 118, 142-231.

[15] R. Huisgen, Angew. Chem. Int. Ed. Engl. 1963, 2, 565-598.

[16] V. V. Rostovtsev, L. G. Green, V. V. Fokin, K. B. Sharpless, Angew. Chem. Int. Ed. 2002, 41, 2596-2599; C. W. Tornøe, C. Christensen, M. Meldal, J. Org. Chem. 2002, 67, 3057-3064.

[17] L. Li, Z. Zhang, Molecules 2016, 21, 1393.

[18] S. D. Köster, J. Dittrich, G. Gasser, N. Hüsken, I. C. Henao Castaneda, J. L. Jios, C. O. Della Védova, N. Metzler-Nolte, Organometallics 2008, 27, 6326-6332.

[19] M. S. Henry, L. Gendron, M.-E. Tremblay, G. Drolet, Neural Plasticity 2017, 2017; J. Hughes, T. W. Smith, H. W. Kosterlitz, L. A. Fothergill, B. A. Morgan, H. R. Morris, Nature 1975, 258, 577-580. 
[20] H. Pfeiffer, A. Rojas, J. Niesel, U. Schatzschneider, Dalton Trans. 2009, 4292-4298.

[21] R. Motterlini, J. E. Clark, R. Foresti, P. Sarathchandra, B. E. Mann, C. J. Green, Circ Res. 2002, 90, e17-e24.

[22] U. Schatzschneider, Br. J. Pharmacol. 2015, 172, 1638-1650.

[23] A. Ismailova, D. Kuter, D. Scott Bohle, I. S. Butle, Bioinorg Chem Appl. 2018, 2018.

[24] S. Pai, M. Hafftlang, G. Atongo, C. Nagel, J. Niesel, S. Botov, H.-G. Schmalz, B. Yard, U. Schatzschneider, Dalton Trans. 2014, 43, 8664-8678.

[25] M. Patra, N. Metzler-Nolte, Chem. Commun. 2011, 47, 11444-11446.

[26] B. B. Kasten, X. Xiaowei Ma, H. Liu, T. R. Hayes, C. L. Barnes, S. Qi, K. Cheng, S. C. Bottorff, W. S. Slocumb, J. Jing Wang, Z. Cheng, P. D. Benny, Bioconjugate Chem. 2014, 25, 579-592.

[27] A. Leonidova, V. Pierroz, L. A. Adams, N. Barlow, S. Ferrari, B. Graham, G. Gasser, ACS Med. Chem. Lett. 2014, 5, 809-814.

[28] V. P. Torchilin, Adv. Drug Deliv. Rev. 2008, 60, 548-558.

[29] S. D. Köster, H. Alborzinia, S. Can, I. Kitanovic, S. Wölfl, R. Rubbiani, I. Ott, P. Riesterer, A. Prokop, K. Merza, N. Metzler-Nolte, Chem. Sci., 2012, 3, 2062 2012, 3, 2062-2072.

[30] L. Casarrubios, M. C. de la Torre, M. A. Sierra, Chem. Eur. J. 2013, 19, 3534-3541.

[31] D. V. Partyka, J. B. Updegraff, M. Zeller, A. D. Hunter, T. G. Gray, Organometallics 2007, 26, 183-186.

[32] I. Peran, T. Oudenhoven, A. M. Woys, M. D. Watson, T. Q. O. Zhang, I. Carrico, M. T. Zanni, D. P. Raleigh, J. Phys. Chem. B 2014, 118, 7946-7953.

[33] N. Fischer-Durand, D. Lizinska, V. Guerineau, B. Rudolf, M. Salmain, Appl. Organomet. Chem. 2019, 33, e4798.

[34] S. F. M. van Dongen, R. L. M. Teeuwen, M. Nallani, S. S. van Berkel, J. Cornelissen, R. J. M. Nolte, J. C. M. van Hest, Bioconjugate Chem. 2009, 20, 20-23.

[35] J. Ohata, F. Vohidov, A. Aliyan, K. Huang, A. A. Martí, Z. T. Ball, Chem. Commun. 2015, 51, 15192-15195.

[36] J. Wang, J. Xue, Z. Yan, S. Zhang, J. Qiao, X. Zhang, Angew. Chem. Int. Ed. 2017, 56, 14928-14932.

[37] P. E. Nielsen, M. Egholm, R. H. Berg, O. Buchardt, Science 1991, 254, 1497-1500.

[38] P. E. Nielsen, Curr. Opin. Biotechnol. 2001, 12, 16-20.

[39] S. A. Thomson, J. A. Josey, R. Cadilla, M. D. Gaul, F. C. Hassman, M. J. Luzzio, A. J. Pipe, K. L. Reed, D. J. Ricca, R. W. Wiethe, S. A. Noble, Tetrahedron 1995, 51, 61796194.

[40] G. Gasser, N. Hüsken, S. D. Köster, N. Metzler-Nolte, Chem. Commun. 2008, 2008, 3675-3677.

[41] A. M. Sosniak, G. Gasser, N. Metzler-Nolte, Org. Biomol. Chem. 2009, 7, 4992-5000.

[42] N. Hüsken, G. Gasser, S. D. Köster, N. Metzler-Nolte, Bioconjugate Chem. 2009, 20, 1578-1586.

[43] A. A. Rashad, R. V. K. Sundaram, R. Aneja, C. Duffy, I. Chaiken, J. Med. Chem. 2015, 58, 7603-7608.

[44] G. Gasser, K. Jäger, M. Zenker, R. Bergmann, J. Steinbach, H. Stephan, N. MetzlerNolte, J. Inorg. Biochem. 2010, 104, 1133-1140.

[45] A. Noor, G. S. Huff, S. V. Kumar, J. E. M. Lewis, B. M. Paterson, C. Schieber, P. S. Donnelly, H. J. L. Brooks, K. C. Gordon, S. C. Moratti, J. D. Crowley, Organometallics 2014, 33, 7031-7043.

[46] S. M. Meier, M. Novak, W. Kandioller, M. A. Jakupec, V. B. Arion, N. Metzler-Nolte, B. K. Keppler, C. G. Hartinger, Chem. Eur. J. 2013, 19, 9297 - 9307. 
[47] C. A. Kluba, T. L. Mindt, Molecules 2013, 18, 3206-3226.

[48] T. L. Mindt, H. Struthers, L. Brans, T. Anguelov, C. Schweinsberg, V. Maes, D. Tourwé, R. Schibli, J. Am. Chem. Soc. 2006, 128, 15096-15097.

[49] X. Zhang, P. Cabral, M. Bates, J.-P. Gambini, M. Fernandez, V. Calzada, F. Gallazzi, B. Larimer, S. D. SFigueroa, O. Alonso, T. P. Quinn, H. S. Balter, S. L. Deutscher, Curr. Radiopharm. 2010, 3, 308-321.

[50] T. L. Mindt, C. Schweinsberg, L. Brans, A. Hagenbach, U. Abram, D. Tourwé , E. Garcia-Garayoa, R. Schibli, ChemMedChem 2009, 4, 529 - 539.

[51] N. J. Agard, J. A. Prescher, C. R. Bertozzi, J. Am. Chem. Soc. 2004, 126, 1504615047.

[52] C. J. Pickens, S. N. Johnson, M. M. Pressnall, M. A. Leon, C. J. Berkland, Bioconjugate Chem. 2018, 29, 686-701.

[53] K. K.-W. Lo, B. T.-N. Chan, H.-W. Liu, K. Y. Zhang, S. P.-Y. Li, T. S.-M. Tang, Chem. Commun. 2013, 49, 4271--4273.

[54] A. W.-T. Choi, H. Liu, K. K.-W. Lo, J. Inorg. Biochem. 2015, 148, 2-10.

[55] S. I. Lim, S. Yoon, Y. H. Kim, I. Kwon, Molecules 2015, 20, 5975-5986.

[56] N. A. Lodhi, J. Y. Park, K. Kim, Y. J. Kim, J. H. Shin, Y.-S. Lee, H.-J. Im, J. M. Jeong, M. Khalid, G. J. Cheon, D. S. Lee, K. W. Kang, Mol. Pharmaceutics 2019, 16, 1586-1595.

[57] M. King, A. Wagner, Bioconjugate Chemistry 2014, 25, 825-839.

[58] E. Decuypère, L. Plougastel, D. Audisio, F. Taran, Chem. Commun. 2017, 53, 11515-11527; S. Kolodych, E. Rasolofonjatovo, M. Chaumontet, M.-C. Nevers, C. Créminon, F. Taran, Angew. Chem. Int. Ed. 2013, 52, 12056-12060; L. Plougastel, O. Koniev, S. Specklin, E. Decuypere, C. Créminon, D.-A. Buisson, A. Wagner, S. Kolodych, F. Taran, Chem. Commun. 2014, 50, 9375-9378; S. Wallace, J. W. Chin, Chem. Sci. 2014, 5, 1742-1744.

[59] D. A. MacKenzie, A. R. Sherratt, M. Chigrinova, L. L. W. Cheung, J. P. Pezacki, Curr. Opin. Chem. Biol. 2014, 21, 81-88; C. S. McKay, J. Moran, J. P. Pezacki, Chem. Commun. 2010, 46, 931-933.

[60] L. C.-C. Lee, H. M.-H. Cheung, H.-W. Liu, K. K.-W. Lo, Chem. Eur. J. 2018, 24, 1406414068.

[61] L. C.-C. Lee, J. C.-W. Lau, H.-W. Liu, K. K.-W. Lo, Angew. Chem. Int. Ed. 2016, 55, 1046-1049.

[62] S. P.-Y. Li, A. M.-H. Yip, H.-W. Liu, K. K.-W. Lo, Biomaterials 2016, 103, 305-313.

[63] T. S.-M. Tang, H.-W. Liu, K. K.-W. Lo, Chem. Commun. 2017, 53, 3299-3302.

[64] R. K. V. Lim, Q. Lin, Acc. Chem. Res. 2011, 44, 828-839; Y. Wang, C. I. Rivera Vera, Q. Lin, Org. Lett. 2007, 9, 4155-4158.

[65] C. Mari, S. Mosberger, N. Llorente, S. Spreckelmeyer, G. Gasser, Inorg. Chem. Front. 2016, 3, 397-405.

[66] D. Kalderon, B. L. Roberts, W. D. Richardson, A. E. Smith, Cell 1984, 39, 499-509.

[67] M. Robaczewska, R. Narayan, B. Beigneres, O. Schorr, A. Thermet, A. J. Podhajska, C. Trepo, F. Zoulim, P. E. Nielsen, L. Cova, J. Hepatol. 2005, 42, 180-187.

[68] A.-C. Knall, C. Slugovc, Chem. Soc. Rev. 2013, 42, 5131-5142.

[69] N. K. Devaraj, R. Weissleder, Acc. Chem. Res. 2011, 44, 816-827.

[70] B. L. Oliveira, Z. Guo, G. J. L. Bernardes, Chem. Soc. Rev. 2017, 46, 4895-4950.

[71] A. W.-T. Choi, K. K.-S. Tso, V. M.-W. Yim, H. Liu, K. K.-W. Lo, Chem. Commun. 2015, 51, 3442--3445.

[72] K. Sonogashira, Y. Tohda, N. Hagihara, Tetrahedron Lett. 1975, 16, 4467-4470.

[73] O. Brosch, T. Weyhermüller, N. Metzler-Nolte, Inorg. Chem. 1999, 38, 5308-5313. 
[74] O. Brosch, T. Weyhermüller, N. Metzler-Nolte, Eur. J. Inorg. Chem. 2000, 323-330.

[75] U. Hoffmanns, N. Metzler-Nolte, Bioconjugate Chem. 2006, 17, 204-213.

[76] H. Eckert, M. Koller, J. Liq. Chromatogr. 1990, 13, 3399-3414.

[77] A. E. Beilstein, M. W. Grinstaff, Chem. Commun. 2000, 509-510.

[78] A. E. Beilstein, M. W. Grinstaff, J. Organomet. Chem. 2001, 637-639, 398-406.

[79] K. Kodama, S. Fukuzawa, H. Nakayama, K. Sakamoto, T. Kigawa, T. Yabuki, N. Matsuda, M. Shirouzu, K. Takio, S. Yokoyama, K. Tachibana, ChemBioChem 2007, $8,232-238$.

[80] N. Li, R. K. V. Lim, S. Edwardraja, Q. Lin, J. Am. Chem. Soc. 2011, 133, 1531615319.

[81] G. T. Hermanson, Bioconjugate Techniques, 2nd ed., Academic Press, San Diego, CA, 2008.

[82] Z. Zhang, B. A. C. Smith, L. Wang, A. Brock, C. Charles Cho, P. G. Schultz, Biochemistry 2003, 42, 6735-6746.

[83] I. S. Carrico, B. L. Carlson, C. R. Bertozzi, Nat. Chem. Biol. 2007, 3, 321-322.

[84] M. Salmain, A. Vessières, in Bioorganometallics, biomolecules, labelling, medicine. (Ed.: G. Jaouen), Wiley-VCH, Weinheim, Germany, 2006, pp. 263-302; M. Salmain, A. Vessières, P. Brossier, I. S. Butler, G. Jaouen, J. Immunol. Methods 1992, 148, 6575; M. Salmain, A. Vessières, G. Jaouen, I. S. Butler, Anal. Chem. 1991, 63, 23232329; A. Vessières, M. Salmain, P. Brossier, G. Jaouen, J. Pharm. Biomed. Anal. 1999, 21, 625-633.

[85] D. A. Tomalia, A. M. Naylor, W. A. Goddard, III, Angew. Chem. Int. Ed. 1990, 29, 138-175; D. A. Tomalia, Prog. Polym. Sci. 2005, 30, 294-324.

[86] N. Fischer-Durand, M. Salmain, B. Rudolf, A. Vessières, J. Zakrzewski, G. Jaouen, ChemBioChem 2004, 5, 519-525; N. Fischer-Durand, M. Salmain, B. Rudolf, L. Juge, V. Guerineau, O. Laprevote, A. Vessieres, G. Jaouen, Macromolecules 2007, 40, 8568-8575; J.-M. Heldt, N. Fischer-Durand, M. Salmain, A. Vessières, G. Jaouen, J. Organomet. Chem. 2004, 689, 4775-4782.

[87] M. M. Banaszak Holl, C. A. Dougherty, S. Vaidyanathan, J. Nanopart. Res. 2018, 20; M. Labieniec-Watala, C. Watala, J. Pharm. Sci. 2015, 104, 2-14; S. Lakew Mekuria, T. Ayane Debele, H.-C. Tsai, RSC Adv. 2016, 6, 63761-63772; S. Svenson, D. A. Tomalia, Adv. Drug Deliv. Rev. 2012, 64, 102-115; R. Vinicius de Araújo, S. da Silva Santos, E. Igne Ferreira, J. Giarolla, Molecules 2018, 23.

[88] N. Fischer-Durand, M. Salmain, B. Rudolf, L. Dai, L. Jugé, V. Guérineau, 0. Laprévote, A. Vessières, G. Jaouen, Anal. Biochem. 2010, 407, 211-219.

[89] S. Pai, K. Radacki, U. Schatzschneider, Eur. J. Inorg. Chem. 2014, 2886-2895. 